2012

\title{
Bending the Health Cost Curve: The Promise and Peril of the Independent Payment Advisory Board
}

Ann Marie Marciarille

J.Bradford DeLong

Follow this and additional works at: https://scholarlycommons.law.case.edu/healthmatrix

Part of the Health Law and Policy Commons

\section{Recommended Citation}

Ann Marie Marciarille and J. Bradford DeLong, Bending the Health Cost Curve: The Promise and Peril of the Independent Payment Advisory Board, 22 Health Matrix 75 (2012)

Available at: https://scholarlycommons.law.case.edu/healthmatrix/vol22/iss1/5 


\title{
BENDING THE HEALTH COST CURVE: THE PROMISE AND PERIL OF THE INDEPENDENT PAYMENT ADVISORY BOARD
}

\author{
Ann Marie Marciarille and J. Bradford DeLong ${ }^{\dagger}$
}

\begin{abstract}
Underlying today's and the future's health-care reform debate is a consensus that America's health-care financing system is in a slowmoving but deep crisis: care appears substandard in comparison with other advanced industrial countries, and relative costs are exploding beyond all reasonable measures. The Obama Administration's Patient Protection and Affordable Care Act (ACA) attempts to grapple with both of these problems. One of ACA's key instrumentalities is the Independent Payment Advisory Board-the IPAB, designed to discover and authorize ways to reduce the rate of growth of Medicare and other categories of health spending. The IPAB is a peril. Expert boards to perform regulatory tasks in the interest of efficiency and social goals always run a high risk of being captured by the industry they are supposed to regulate. Even should it succeed at its task of reducing the rate of growth of Medicare spending, who is to say that the reductions will not come at a heavy cost in reduced quantity and effectiveness of medical care? But the IPAB also has promise. The need for a better process than our current specialist-driven one to assign value to the medical services provided by Medicare is great. The bellwether status of Medicare payment systems means that commercial insurance consumers and payors would also benefit

\footnotetext{
$\dagger$ Visiting Assistant Professor at the University of California Hastings College of the Law, and Professor at the University of California at Berkeley, respectively. This research was partially supported by U.C. Hastings College of the Law and by a grant from the U.C. Berkeley Coleman Fung Risk Management Center. We would like to thank Lauren McCaskill, Henry Aaron, David Cutler, Merrill Goozner, Lane Kenworthy, Maggie Maher, Rika Onishi Mortimer, Peter Orszag, and Christina Romer, among others, for helpful discussions-without implicating them in our conclusions
} or arguments. We thank Anita Pandhoh for excellent research assistance.
\end{abstract}


mightily from bringing more coherent, technocratic, and costeffectiveness oriented logic to this process. And the current system of relative Medicare reimbursement rates is, in the judgment of many, currently well out of whack. We quail when we consider the magnitude of the tasks the IPAB faces-even its initial task. Nevertheless, we remain optimistic that this administrative agency will manage to bend the long-run healthcare cost curve and moderate future price increases.

\section{TABLE OF CONTENTS}

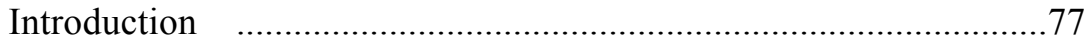

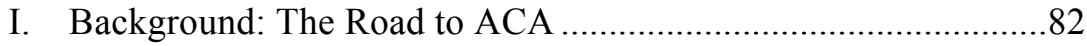

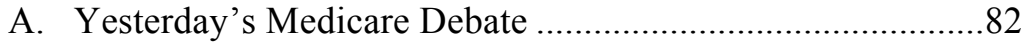

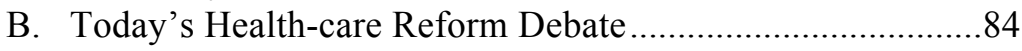

C. A Poorly-Performing Health-care System.............................85

D. Tomorrow's Reform of the Health-care Financing System ..87

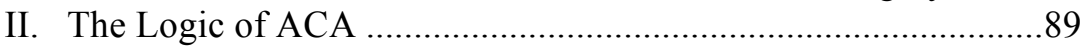

A. Dealing with the Problem of Uninsurance ............................89

B. Reducing the Deficit: Revenues from ACA ...........................90

C. Bending the Medicare Cost Curve through the IPAB ...........92

III. The Independent Payment Advisory Board ..................................93

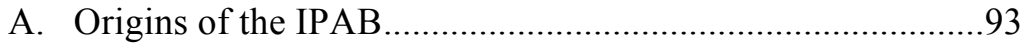

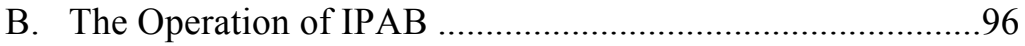

IV. IPAB and the Medicare Physician Fee Schedule …….................99

A. The Importance of the Medicare Physician Fee Schedule ....99

B. What Is the Problem to Which IPAB Is the Solution? .........101

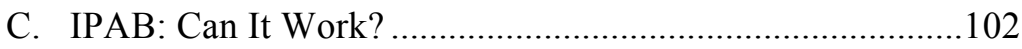

1. The Sustainable Growth Rate Formula .........................102

2. Will IPAB Do Better than MedPAC?.............................103

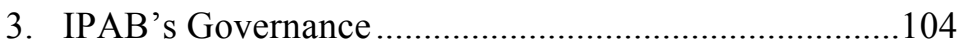

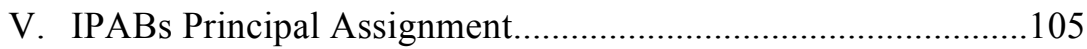

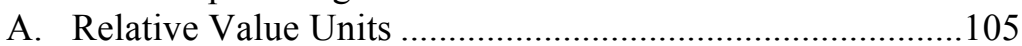

B. The RVS Update Committee...............................................107

C. Why Medicare Physician Reimbursement Relative Value Units Should Matter to IPAB ......................................108

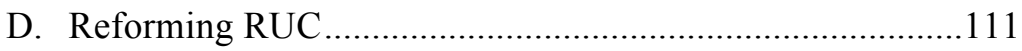

E. The Physician Payment Sustainable Growth Rate

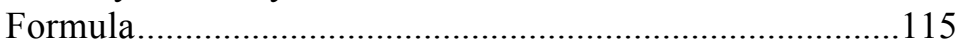

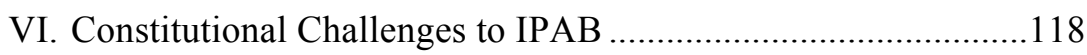

A. Separation of Powers ......................................................118

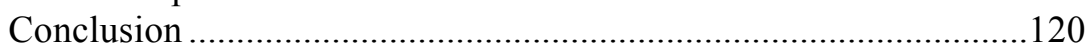




\section{INTRODUCTION}

Underlying the current and future health-care reform debate is a consensus that the American health-care financing system is in a slow-moving but deep crisis.

\section{Figure 1: Life Expectancy and Health Expenditures per Capita in the OECD}

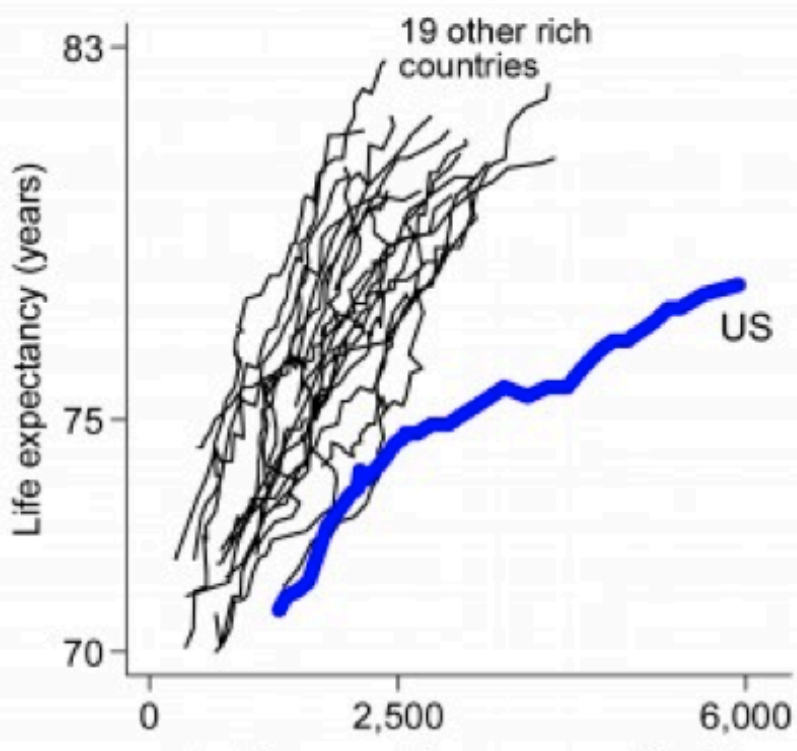

Health expenditures per capita (\$)

Source: Lane Kenworthy calculations from OECD data.

It is conventional wisdom among health policy analysts that over the past generation America's hybrid health-care system has fallen far short, measured against the yardstick of health-care expenses and outcomes in other developed economies. Figure 1 shows an especially striking slice of the cross-national comparative quantitative data. ${ }^{1}$ Up until the end of the 1970s, the United States was, in both life expectancy and health expenditures, in the outfield but still in the ballpark relative to its natural yardstick countries. Since the start of the 1980s, the United States' trajectory has diverged: life expectancy

Lane Kenworthy, America's Inefficient Health-Care System: Another Look, CONSIDER THE EVIDENCE (July 10, 2011), http://lanekenworthy.net/2011/07/10/americas-inefficient-health-care-system-anotherlook/. 
has risen more slowly and health costs have ballooned much more rapidly than in the natural yardstick countries. ${ }^{2}$

The reaction to this slow-moving but deep crisis over the past generation has been recurrent cries for and attempts to pass comprehensive health-care reform not just to improve access to health care and improve the quality of health care but also to "bend the cost curve"- to control rising costs. The latest attempt to reform America's health-care delivery and financing systems is the Patient Protection and Affordable Care Act of 2010 (ACA). The three most important foci of the ACA were indeed (1) to improve access to health care, (2) to improve the quality of health care, and (3) to control costs.

The principal instrumentality for this third goal of the ACA is its establishment of the Independent Payment Advisory Board (IPAB), an administrative board whose principal initial task will be the reform of Medicare's procedure-based reimbursement system. Medicare pricing is notoriously byzantine and poorly understood. It is also desperately important for long-run cost control. It is not an overstatement to say that the long-term viability of social insurance in America depends on whether IPAB is able to successfully manage Medicare pricing.

This Article attempts to lay out the IPAB's assigned tasks, and assess its ability to succeed. That is best accomplished by telling the story of how Medicare currently organizes physician payment, and how it is to be reformed. We quail when we consider the magnitude of the tasks the IPAB faces-even its initial task. Nevertheless, we remain optimistic that this administrative agency will manage to bend the long-run health-care cost curve, and moderate future price increases.

Our current political debate about health care is really three debates.

The first is a debate about the proper reach of the social insurance state: how much access to how much medical care do we wish our health-care financing and delivery systems to provide, particularly for

2 The natural yardstick countries for the United States consist, generally, of other western industrialized countries: Western Europe, Canada, and Japan, Australia, and New Zealand on the Asian Pacific Rim. Similar patterns of demography, levels of prosperity, access to technology, and political economy suggest that outcomes attainable in any of these countries should also be attainable in others. It is worth noting that the Canadian federal government and the Canadian provinces are also working to develop a balanced and sustainable health-care growth rate through the development of a federal-province escalator formula tied in some way to Canada's GDP. See Randall Palmer, Canada Seeks a Way to Limit Health-Spending Increases, REUTERS (Dec. 14, 2011, 5:19 PM), http://www.reuters.com/article/2011/12/14/uscanada-health-spending-idUSTRE7BD2CO20111214. 
those with limited means? The second is a debate about how much of a role the government will take in the health-care financing and delivery systems: In other words, markets or bureaucracies? Government as backstop or provider? Decentralized or centralized?

The subject of this Article is the third debate: How much healthcare spending can Americans afford? And, in the end, how do we structure our health-care financing system so that we do not conclude that the ambitions of the social insurance system are quite literally unaffordable? Today's political debate about health-care reform is thus about our desire and ability to "bend the cost curve" as a decisive factor in the future of government-funded, supported, and regulated health insurance.

This third debate is especially important because the American health-care system delivers less bang for more buck than do the health-care financing and delivery systems of the natural yardstick nations. American patients are less healthy and pay more. Successful health-care reform and successful health-care policy management must require a more efficient health-care financing system. That is what the ACA's cost-control provisions are intended to produce.

At the heart of the ACA's cost-control provisions is the IPAB. ${ }^{3}$ From 2015 on, in any year which the Medicare Actuary forecasts that net spending growth will exceed target levels, the IPAB is charged with developing specific proposals to bring the net growth in Medicare spending back to target levels. ${ }^{4}$ The IPAB is forbidden from raising taxes, increasing Medicare premiums, increasing Medicare co-payments or deductibles, or in any way rationing health care. $^{5}$ Given all these things that the IPAB cannot do, what can the IPAB do? The low-hanging fruit that the IPAB is intended to first and most importantly pick is to alter the process by which Medicare sets its outpatient reimbursement rates. ${ }^{6}$

The functioning of the IPAB will be an experiment by Congress

\footnotetext{
3 See Henry J. Aaron, The Independent Payment Advisory Board - Congress's “Good Deed", 364 New EnG. J. Med. 2377, 2378 (2011).

${ }^{4}$ From 2015 to 2019 , the target growth rate will be based on a synthesis of the Consumer Price Index for All Urban Consumers ("CPI-U") and the medical care expenditures category in the CPI-U. From 2020 forward (based on determination year 2018 data for proposal year 2019 and implementation year 2020) the target for spending will be linked to the growth in the national gross domestic product ("GDP per capita") plus one percentage point. The transition to a Medicare growth rate linked to GDP per capita will occur first by linking to growth in health-care prices and, eventually, by linking to growth in the larger economy. 42 U.S.C. § $1395 \mathrm{kkk}(\mathrm{c})(2)(\mathrm{A})(\mathrm{i})(2010)$.

5 Id. $§ 1395 \mathrm{kkk}(\mathrm{c})(2)(\mathrm{A})(\mathrm{ii})$.

${ }^{6}$ See Aaron, supra note 3, at 2378.
} 
in binding itself to the mast, as Odysseus did when confronted by the Sirens. In the past Congress has exercised its discretion to reject-or, rather, to fail to act on-proposals to reform Medicare reimbursement rates put forward by entities Congress created to advise it. The belief is that the IPAB process, which removes much of Congress's discretionary authority not to act over recommendations on rates, will lead to Medicare payment decisions that are closer to the social optimum. $^{7}$

This ambitious attempt to reform Medicare physician payments via the IPAB is also the weak point of the ACA. It carries all of the tension between collective overconsumption and overspending on the one hand and less-than-socially-optimized individual choices on the other. ${ }^{8}$ How can the IPAB's proposals slow the growth of Medicare spending without imposing an unacceptably high cost in terms of reduced quality or amount of care? The IPAB, if it works, will harness the enormous purchasing power of the federal Medicare program for the task of bending the cost curve not just for Medicare alone but for health care in general by reworking physician payment standards. But if it is to work at acceptable cost it must trigger improvements in the efficiency of the health-care delivery system and not just say "no" to cost increases."

The long-run effects of the IPAB on health-care costs-if the Board survives, and if its implementation is successful-are projected to be enormous. The Congressional Budget Office (CBO) projects that, as of 2040, federal expenditures on health care will be lower by 2 percent of Gross Domestic Product (GDP)—or $\$ 600$ billion each

7 Congressional authority to delegate power under broad general directives is grounded in the understanding that complex technical problems may require delegation of legislative power in complex technical areas. See generally Mistretta v. United States, 488 U.S. 361, 372 (1989) (recognizing that increasingly complex technical problems may require Congressional ability to delegate power under broad general directives).

${ }^{8}$ The problem of distributive justice is particularly acute in a society where health-care expenditures exceed 16 percent of GDP. The inherent difficulty of allocative decisions is enhanced by our society's insistence that allocative decisions are not made - by patients, providers, and payors - on a daily basis. The Long-Term Outlook for Health Care Spending, CONG. BudGet OfF. http://www.cbo.gov/ftpdocs/87xx/doc8758/maintext.3.1.shtml (last visited Oct. 26, 2011).

${ }^{9}$ Cf. Edmund F. Haislmaier, Compromising Quality: The High Cost of Government Drug Purchasing, Heritage Found. 2 (May 25, 2004), http://thf_media.s3.amazonaws.com/2004/pdf/bg1764.pdf (arguing that government intervention in the prescription drug market through market access controls diminishes health-care quality). 
year-because of the successful implementation of the ACA. ${ }^{10}$ If these forecasts are accurate, the IPAB would slow the growth in costs of today's existing federal health-care programs by a third over the next generation, with the savings coming overwhelmingly from Medicare. $^{11}$

The IPAB is a peril. Expert boards to perform regulatory tasks in the interest of efficiency and social goals always run a high risk of being captured by the industry they are supposed to regulate. Even if it should succeed at its task of reducing the rate of growth of Medicare spending, who is to say that the reductions will not come at a heavy cost in reduced quantity and quality of medical care?

But the IPAB also has promise. The need for a better process than our current specialist-driven one to value the medical services provided by Medicare is great. The bellwether status of Medicare payment systems means that commercial insurance consumers and payers would also benefit mightily from bringing more coherent, technocratic, and cost-effectiveness oriented logic to this piece of the American government. And the current system of relative Medicare reimbursement rates is, in the judgment of many, currently well out of whack.

10 Compare Cong. Budget Off., The Long-Term Budget Outlook (2010), available at http://www.cbo.gov/ftpdocs/115xx/doc11579/06-30-LTBO.pdf with Cong. Budget Off., The Long-Term Budget Outlook (2009), available at http://www.cbo.gov/ftpdocs/102xx/doc10297/06-25-ltbo.pdf. The CBO does not make it easy for its readers to untangle just how Congressional actions and changes in the economic environment interact to change its estimates of the long-run path of federal spending and revenues. However, Table 1-3 on page 15 of the Long-Term Budget Outlook for 2010 shows a drop in the projected 50-year extended-baseline fiscal gap between program spending and revenues from 2.6 percent of GDP projected in June 2009 to 0.8 percent of GDP projected in June 2010. THE LONG-TERM BudGET OUTLOOK (2010), supra. On the revenue side, revenues are boosted by the ACA's tax on high-cost health plans. Id. at 37. On the spending side, even the introduction of subsidies so that low- and moderate-income households without employersponsored insurance can afford to purchase health insurance via the ACA's Exchanges and the remarkably-large expansion of Medicaid under the ACA are projected to be offset by other savings. Id. at 36. The only place that such significant other savings could possibly come from in the CBO's budget arithmetic is from the effects of the IPAB in bending the cost curve of federal Medicare spending.

11 Savings would come secondarily from reduced Medicaid expenditures. Improved efficiency in the health-care system would mean that more elderly would be able to afford their Medicare cost-sharing without having to draw on Medicaid. If Medicare does indeed serve as a "price leader" in the antitrust sense and private insurance companies key their reimbursement rates to Medicare rates, there will be additional savings to the Federal government that will come from reduced subsidy payments to low-income Americans purchasing health insurance through the statelevel health exchanges. However, these potential savings are speculative, and are not included in $\mathrm{CBO}$ estimates. 
[Vol. 22: 75]

We quail when we consider the magnitude of the tasks the IPAB faces-even its initial task. Nevertheless, we remain optimistic that this administrative agency will manage to bend the long-run healthcare cost curve and moderate future price increases.

\section{BACKGROUND: THE ROAD TO THE ACA}

\section{A. Yesterday's Medicare Debate}

The origins of our current health-care dilemmas as they affect the federal budget - especially related to Medicare's provider reimbursement system - are found in the 1960s. The presidential election of 1964 had powerful consequences. Democratic President Lyndon Baines Johnson not only won election over Republican nominee Barry Goldwater, Johnson carried with him the largest supporting congressional majorities since Franklin Delano Roosevelt. ${ }^{12}$

One major consequence of Johnson's victory was the establishment of Medicare and Medicaid. These two programs transformed America's health-care financing system from a system funded by private charity, out-of-pocket payments, and private insurance (for those lucky enough to work for large and high-wage businesses) to the hybrid system we have today. ${ }^{13}$ Currently, half of America's health-care financing system is composed of this mix of charity, out-of-pocket, and insurance. ${ }^{14}$ The other half is comprised of the federal single-payer system for elderly and some disabled persons, called Medicare, and the federal/state single-payer system for poor and most disabled persons, called Medicaid. ${ }^{15}$ Together, they bring us materially closer to providing a safety net for Americans who find themselves in need of health care, but lack the financial resources to pay for it.

12 Given the role played by Barry Goldwater's decision to challenge establishment Republicans like George Romney and Nelson Rockefeller in creating the Democratic-heavy legislative environment in 1965 and 1966 that enabled the creation of Medicare, there is some irony in the role of the Goldwater center's active presence in today's court cases seeking to hobble the reform of Medicare. See generally Complaint at 30-31, Coons v. Geithner, No.2:10cv1714 (D. Ariz., May 10, 2011) (challenging Congress's creation of the Independent Payment Advisory Board (IPAB) as an unconstitutional delegation of Congressional powers to an unelected, unaccountable executive agency).

13 See Paul Starr, The Social Transformation of American Medicine 147-49, 369 (1982).

${ }_{14}$ Peter Landers, Public Share of Health Tab to Top 50\%, WALL ST. J., Feb. 4, 2010, at A1.

15 Laura Katz Olson, The Politics of Medicaid 1, 26 (2010). 
As the bill that was to establish Medicare and Medicaid moved through Congress in 1965, President Johnson sought to derail a threatened American Medical Association (AMA) boycott of his program. Johnson decided to offer doctors participating in Medicare generously-structured payment rules with little government oversight. ${ }^{16}$ Doctors would report to the government what they charged their non-Medicare patients for the services they provided to Medicare patients, and the government would pay the bill. There was no bureaucracy to intrude into doctors' practices, and there were no accountants to demand a discount for the large buyer that was the nationwide government program. ${ }^{17}$

The particular minimal-supervision payment rules Johnson established did not survive beyond the early 1980s. ${ }^{18}$ Nevertheless, Johnson's decision to establish this particular Medicare provider reimbursement system still casts its shadow over Medicare and is one major source of the current projection fiscally-unsustainable Medicare cost growth. ${ }^{19}$ If IPAB succeeds, it will switch us off of the track that

16 David Blumenthal \& James A. Morone, The Heart of Power: Health and Politics IN the Oval Office 201 (2009).

17 In part, this was a response to rent-seeking by well-organized doctors looking to preserve their incomes and fearing the long-run effects of becoming an industry subject to heavy government regulation. On the one hand, the government was promising to boost demand by paying for their services. On the other hand, the government seemed likely to extend control. For an overview of how groups like doctors are successful in manipulating the government in such situations, see Mancur Olson, The Logic of Collective ACTION (1966). The ideological reaction to Medicare proposals was remarkably intense, as was the political heat. Consider Representative Hallock of Indiana's claim that after the passage of Medicare it would be impossible to preserve freedom for long in America: "We do not want socialized medicine .... When the American people wants [sic] something from Congress, regardless of its political complexion, if they make their wants known, Congress does what the people want . . . ." Eric Zorn, Ronald Reagan on Medicare, Circa 1961. Prescient Rhetoric or Familiar Alarmist Claptrap?, ChiCAgo Tribune Blog (Sept. 2, 2009, 2:00 PM), http://blogs.chicagotribune.com/news_columnists_ezorn/2009/09/ronald-reagan-onmedicare-circa-1961-prescient-rhetoric-or-familiar-alarmist-claptrap-.html. Ronald Reagan agreed, and warned that "behind [Medicare] will come other federal programs that will invade every area of freedom as we have known it in this country until one day, as Norman Thomas said, we will wake to find that we have socialism . . . . [W]e are going to spend our sunset years telling our children, and our children's children, what it once was like in America when men were free." Id.

18 As discussed below, in the 1980s the U.S. government began to tighten its control over Medicare payments in an attempt to standardize valuation of care in a process led by Dr. William Hsiao of the Harvard School of Public Health. See infra Part V.A.

19 As of 2007, before the beginning of the latest health-care reform debate, the $\mathrm{CBO}$ was projecting that in the absence of fundamental reforms to the federal laws governing the Medicare and Medicaid programs, "[f]ederal spending on Medi- 
Johnson started us down in 1965.

\section{B. Today's Health-care Reform Debate}

The three debates that make up our current struggle over healthcare reform are conducted at three very different levels of generality.

The first is a debate about moral philosophy. Whose responsibility is it to assemble the resources to pay for the medical care that we will all seek over the course of our lifetimes? How much of the cost of medical care should properly rest on the individual seeking care? Does our answer to this change depending on whether the diseases needing treatment are "in the genes," "in the lifestyle," or appear to be simply accidental bad luck? How much of the cost of medical care should rest on groups of individuals, using private insurance companies as instrumentalities to voluntarily associate with one another to pool and spread risk? And how much of the cost of medical care is within the proper reach of the social insurance stateparticularly for those with limited means? These questions of individual responsibility and social justice raised in this debate are important, divisive, and unresolved. We cannot deal with them in this paper.

The second is a debate about the proper boundary between the market and the state. Historically, there have been some areas from which we have broadly excluded the market. Americans have always elected or had their elected officials appoint judges and police chiefs, we have not bought judicial services from the lowest bidder, or allowed the low-bidding private security company to exercise the police powers of the state. Similarly, our military has always been a military of volunteers or conscripts, and not an assembly of mercenary companies. Education and health care, too, have historically been overwhelmingly provided by nonprofit or public institutions rather than by for-profit corporations. Even health insurance was, until recently, largely nonprofit and mutual. While in much of our society it is taken for granted that the market will provide, health care has been somewhat different. Should it have been? Should it still be? The second debate is about how much of a role the government ought to take in health-care financing and delivery systems. Should the government be a provider or merely a financer? Should the system as

care (net of beneficiaries' premiums) and Medicaid would rise from 4 percent of GDP in 2007 to 7 percent in 2025, 12 percent in 2050, and 19 percent in 2082." State spending on Medicaid would be in addition to federal spending. CONG. Budget OfF., The Long-Term Outlook for HeAlth CARE SPENDing 2 (2007), available at http://www.cbo.gov/ftpdocs/87xx/doc8758/11-13-LT-Health.pdf. 
a whole be decentralized or centralized? How much do we trust markets, and how much do we trust bureaucracies? Once again, these questions raised in this debate are important, divisive, and unresolved. We cannot deal with them in this paper.

The subject of this Article, then, is the third debate. How much health-care spending can Americans afford? And, in the end, how do we structure our health-care financing system so that we do not conclude that the ambitions of the social insurance system are quite literally unaffordable? The fact that the American health-care system delivers less bang for more buck than do the health-care financing and delivery systems of the natural yardstick nations creates a rebuttable presumption that we are, in some way, doing it wrong. It would be understandable - a coherent social choice - if American patients were less healthy but paid less. It would be understandable if American patients were more healthy and paid more. But Americans are less healthy and pay more.

This fact leads to the conclusion that, no matter what the results or positions are in debates one and two, there is space for a health-care reform and successful health-care policy management that will produce a different and more efficient health-care financing system. That is what the ACA is intended to produce. The ACA largely ducked the first two debates, creating a complicated public-private system that could accommodate nearly any set of answers to those two. But it does seek to push the health-care financing system in the direction of greater efficiency-because the need is urgent.

\section{A Poorly-Performing Health-care System}

Our current hybrid health-care system leaves us at any particular moment with about 50 million Americans without any form of health

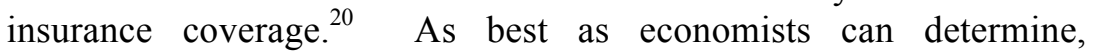
America's uninsured get perhaps half the care standard for other

${ }^{20}$ See Press Release, U.S. Census Bureau, Income, Poverty and Health Insurance Coverage in the United States: 2010 (Sept. 13, 2011), available at http://www.census.gov/newsroom/releases/archives/income_wealth/cb11-157.html. Before the recession, over a typical four year period, approximately twice as many Americans experienced a gap in insurance coverage as suffered from one at any single point in time. Before the recession, about two-thirds as many people as those uninsured at any point in time lack coverage more than half the time. The recession beginning in 2008 altered these patterns in ways impacting the reliability of these types of predictions. See, e.g Pamela Farley Short, Deborah R. Graefe \& Cathy Schoen, Churn, Churn, Churn: How Instability of Health Insurance Shapes America's Uninsured Problem, Commonwealth Fund 1, 4-5 (Nov. 2003), http://www.commonwealthfund.org/usr_doc/Short_churn_688.pdf. 
Americans. $^{21}$ The consequence is that Americans achieve worse health outcomes than do the citizens of any other rich, industrialized country. Americans' life expectancy at birth now lags behind the industrial country average by approximately four years. ${ }^{22}$ It is true that the life expectancy gap is due in part to relatively unhealthy aspects of the contemporary American lifestyle. Smoking, poor nutrition, and suburbanization have taken their toll. ${ }^{23}$ But the gap in life expectancy has grown far larger over the past generation even as smoking rates have declined, nutritional standards have improved, and suburbanization has remained constant. ${ }^{24}$

Moreover, the uninsured receive a disproportionate amount of their health care at relatively expensive, low follow-up emergency rooms, and thus get their care in a way that guarantees low value-formoney. ${ }^{25}$ This contributes to the other aspect in which American health care falls well short: America's health-care costs are much higher than in other countries. However, other contributing factors are even more important. The U.S. system has extraordinarily high administrative costs relative to other nations, because insurance companies face enormous bottom-line incentives to deny payment for even the most necessary and appropriate care. ${ }^{26}$ The U.S. system compensates and uses the most expensive medical care providersspecialists - at a rate vastly exceeding other economies. ${ }^{27}$ Health

${ }^{21}$ Catherine Hoffman, Anthony Damico \& Rachel Garfield, Research Brief: Insurance Coverage and Access to Care in Primary Care Shortage Areas, KAISER FAMILY FounD. 1 (Feb. 2011), http://www.kff.org/insurance/upload/8161.pdf.

${ }^{22}$ See Kenworthy, supra note 1.

23 Explaining Divergent Levels of Longevity in High-Income Countries 3-4 (Eileen M. Crimmins, Samuel H. Preston, \& Barney Cohen, eds., 2011) available at $\mathrm{http}: / / \mathrm{www} . n a p . e d u /$ catalog.php?record_id=13089 (describing how the built environment, including the development of suburban housing designed primarily for automotive access, has implications for morbidity and mortality).

${ }^{24}$ See generally Gary King \& Samir Soneji, The Future of Death in America, 25 DemOgRAPHIC RES. 1 (July 1, 2011), http://www.demographicresearch.org/volumes/vol25/1/25-1.pdf.

25 See, e.g. Sarah Miller, The Effect of Insurance on Emergency Room Visits: An Analysis of the 2006 Massachusetts Health Reform 3, 6 (University of Illinois at Urbana-Champaign Working Paper Series, Sept. 1, 2011), available at http://papers.ssrn.com/sol3/papers.cfm?abstract_id=1711502.

${ }_{26}$ See Mark J. Browne, Evidence of Adverse Selection in Health Care Markets, 59 J. RISK \& INS. 13, 27 (1992); see also Scot J. Paltrow, Insurers' Black Box: Now-Secret Claims Denied Rates Could Tell Consumers a Lot About Their Insurance Company, CTR. FOR AM. PROGRESS 1 (Oct. 21, 2009), http://www.americanprogress.org/issues/2009/10/pdf/insurers_black_box.pdf.

27 See generally AmitaBh ChANDRA \& KATHERINE BAICKER, THE Productivity of Physician Specialization: Evidence from the Medicare PROGRAM (2004), available at http://www.dartmouth.edu/ kbaicker/BaickerChandraSpecialists.pdf ; see also CHRIS 
policy experts argue about the impact of pressure to provide more and more sophisticated care that is reinforced by the medical malpractice system. The general consensus, though, points instead to a lack of knowledge and consensus about which procedures and protocols are actually effective and appropriate. ${ }^{28}$ One informed guess indicates that about one-third of all care provided carries a social cost greater than the benefit to the patient. Another informed guess states that a substantial part of health-care spending is at best neutral from the perspective of likely patient outcomes. ${ }^{29}$

In addition, the performance of the American health-care system, relative to other countries, is likely to become worse over time. Nearly all projections anticipate that American medical costs will also continue to rise, and at a rate faster than that of other industrialized economies. $^{30}$

\section{Tomorrow's Reform of the Health-care Financing System}

Breaking this trend-bending the cost curve - is thus essential.

Bending the cost curve means making changes to the health-care delivery and finance system to decrease the rate at which health-care spending increases. ${ }^{31}$ Even in the universe of government funded

L. Peterson \& Rachel Burton, Cong. Research Serv., Rl34175, U.S. Health CARE SPENDING: COMPARISON WITH OTHER OECD COUNTRIES 41 (2007), available at http://assets.opencrs.com/rpts/RL34175_20070917.pdf.

28 David M. Cutler, Your Money or Your Life: Strong Medicine for AMERICA's HEALTH CARE SYSTEM 107 (2004); the book's immensely valuable technical appendix is also available at http://economics.harvard.edu/faculty/cutler/files/technical_appendix.pdf. See generally LEIGHANNE OLSEN ET AL., LEARNING WHAT WORKS: INFRASTRUCTURE REQUIRED FOR COMPARATIVE EFFECTIVENESS RESEARCH 57 (2011), available at http://www.nap.edu/catalog.php?record_id $=12214$ (providing an overview of the many publications that have highlighted the limited quality of the evidence developed to guide health-care decision makers).

29 Jonathan Gruber, Health Care Reform: A Graphic Novel, Boston GLoBE, http://www.boston.com/lifestyle/health/gallery/health_care_graphic_novel/ (last visited Jan. 23, 2012). See also Christopher P. Landrigan et al., Temporal Trends in Rates of Patient Harm Resulting from Medical Care, 363 NEw Eng. J. MED. 2124, 2130 (2010). Perhaps 75,000 people a year in America die from medical error. Ellen Nolte \& C. Martin McKee, Measuring the Health of Nations: Updating an Earlier Analysis, 27 HeAlth AfF. 58, 63 (2008).

30 See, e.g. 2011 Global Medical Trends Survey Report, TOWERS WATSON (2011), http://www.towerswatson.com/assets/pdf/3585/Towers-Watson-GlobalMedical-Trends-Svy-Rpt.pdf.

31 Though the origins of the phrase "bending the cost curve" are obscure, William Safire attributes the migration of the aviation reference to being behind the 
health insurance, Americans are uncertain who can bend the cost curve, and for good reason. Short of absolute fiat, the health-care cost curve will not improve without changes in provider, payor, and consumer behavior. In a hybrid public/private health-care systemsuch as our own-many private players have a role in determining government funded health-care expenditures. It is a collective action problem, ${ }^{32}$ amenable only to collective, systemic solutions to overcome collective overconsuming and overspending. ${ }^{33}$

In the absence of successful implementation of comprehensive health-care reform, observers have noted five features of the ongoing process of health-care cost growth.

First, rapidly-rising publicly funded insurance health-care expenditures are not being driven by a shifting of costs away from private payors - charity, out-of-pocket, and private insurance - to the public. Private and public costs and expenditures are rising in tandem, with the public side, if anything, better at achieving efficiencies and evading cost-shifting in health-care provision. ${ }^{34}$

Second, the destructive adverse selection arms race among the private insurance companies and others continues, with the company that does least well paying a disproportionate share of the bills, and winding up in the red. The result is that much of the increase in health-care costs on the private side is directed towards administrative overhead in order to further exploit adverse selection. There are, so far, no signs that this arms race has come to an end or even stabilized at a constant proportional share of health-care expenditures. The incentives in the current system for insurers to find ways not to pay for the sick, and for the healthy to find ways not to pay into the system are simply too great ${ }^{35}$.

\footnotetext{
power curve to no one less than President Obama himself. William Safire, Bending the Curve, N. Y. TimEs, Sept. 13, 2009, at MM14.

${ }^{32}$ Austin Frakt, Bending the Curve: Conflict and Skepticism, INCIDENTAL ECONOMIST (Oct. 6, 2010, 10:00AM), $\mathrm{http}$ //theincidentaleconomist.com/wordpress/bending-the-curve-conflict-andskepticism/.

${ }^{33} I d$.

34 Cong. Budget Off., Key Issues in Analyzing Major Health INSURANCE REFORM PROPOSALS 19 (Dec. 2008), available at http://www.cbo.gov/ftpdocs/99xx/doc9924/12-18-KeyIssues.pdf.

35 See generally Karen Eggleston \& Anupa Bir, Measuring Selection Incentives in Managed Care: Evidence From the Massachusetts State Employee Insurance Program, 76 J. RisK \& INS. 159, 161 (2009) (explaining how capitation only exascerbates insurer cherry picking); see also Tom Baker \& Peter Siegelman, Tontines for the Invincibles: Enticing Low Risks Into the Health Insurance Pool With An Idea From Insurance History and Behavioral Economics, 2010 WIS. LAW REV.79 (2010)
} 
Third, the growing gap in life expectancy between rich and poor Americans strongly suggests that the care gap between the insured and the uninsured is growing as well. ${ }^{36}$

Fourth, the aging of the population and the resulting increase in per capita costs of care as those suffering from the diseases of aging become a larger and larger share of the population - while very realis not a primary driver of increased costs. ${ }^{37}$

Instead, fifth, the principal driver of anticipated system-wide cost increases is the creation and deployment of additional medical care technologies and protocols. Physicians and insurers are the gatekeepers who decide when and how additional medical care technologies and protocols will be deployed ${ }^{38}$.

\section{THE LOGIC OF THE ACA}

Thus the ACA is motivated by a desire to fix the two major deficiencies of the American health-care financing system measured against the yardstick of other OECD economies.

\section{A. Dealing with the Problem of Uninsurance}

The ACA proposes to address the problem of the uninsured's lack of access to affordable care by, first, a large expansion of the federal/state Medicaid program. ${ }^{39}$ This will definitely not reduce health-care costs: providing 15 million people with financing so that they can go to the doctor more often is not a cost-reducing measure.

The ACA proposes, second, to address the problem of the middle class uninsured's inability to purchase affordable insurance by creating fifty state-specific health exchanges, each of which will increase bargaining power and mitigate adverse selection. The hope is that these reforms will increase competition in the health insurance

(discussing the one-third of young men who will not voluntarily purchase health insurance).

36 Explaining Divergent Levels of Longevity IN High-Income COUNTRIES, supra note 23, at 117.

37 Long-Term Outlook for Health CARe Spending, supra note 19, at 3.

38 Christine Lane \& Barbara J. Turner, The Good (Gatekeeper), the Bad (Gatekeeper), and the Ugly (Situation), 14 J. Gen. InTERnAL Med. 320, 320 (1999); Thomas Bodenheimer et al., Primary Care Physicians Should Be Coordinators, not Gatekeepers, 281 JAMA 2045, 2045 (1999); Melvin Kirschner, I Am a Physician, Don't Call Me a Gatekeeper, L.A. TIMES (Sept. 3, 1995), available at http://articles.latimes.com/1995-09-03/local/me-41803_1_patient-care.

39 See Chris L. Peterson, Medicaid Coverage Expansions Under PPACA: Who and How Much, CONG. Res. Serv. (May 7, 2010), http://www.nhpf.org/library/handouts/Peterson.slides_05-07-10.pdf. 
markets by diminishing the bargaining power of large insurers vis-àvis individuals and small groups. If successful, administrative costs will fall greatly once community rating ${ }^{40}$ and the individual mandate reduce the incentive to engage in the adverse selection arms race. Private health-care costs will decline, as will government costs, to the extent that those purchasing health insurance on the exchanges or elsewhere benefit from the federal subsidy pool. But the exchanges and the federal subsidy pool will also make it possible for approximately 20 million more people to go to the doctor more often. Once again, providing millions of people with financing so that they can go to the doctor more often is not a cost-reducing measure. ${ }^{41}$

The cost-saving and deficit-reducing measures in the ACA are found elsewhere.

\section{B. Reducing the Deficit: Revenues from the ACA}

Nobody knows how effective the ACA will be. It depends on the details of implementation, the functioning of the health-care market, and future changes that are unknowable. The Congressional Budget Office (CBO) has, however, projected the impact of the ACA which serves as a useful baseline and starting point. ${ }^{42}$ We consider the $\mathrm{CBO}$ projections below.

One of the largest single projected effects of the ACA is a federal tax revenue increase of $\$ 600$ billion per year by $2040 .{ }^{43}$ This increase is due to a substantial excise tax on "high cost" health insurance plans. $^{44}$ This tax can be thought of as a partial reduction in the tax

${ }^{40}$ Community rating requires health insurers offer every applicant in the pool the opportunity to purchase insurance at a uniform community-wide price. The opposite of community rating is found in products that are individually underwritten and individually priced. Uwe R. Reinhardt, Is 'Community Rating' in Health Insurance Fair?, ECONOMIX: N.Y. TIMES BLOG (Jan. 1, 2010, 7:01 AM), http://economix.blogs.nytimes.com/2010/01/01/is-community-rating-in-healthinsurance-fair/.

${ }^{41}$ Katherine Balcker \& Amitabh Chandra, Misconceptions About Health Insurance Markets and Health Reform, TIAA-CREF INSTITUTE 2 (Feb. 2011), http://www.tiaacref.org/ucm/groups/content/@ap_ucm_p_tcp_docs/documents/docu ment/tiaa02029346.pdf.

42 Cong. Budget Off., An Analysis of Health Insurance Premiums Under the Patient Protection and AfFordable Care Act 23-27 (Nov. 30, 2009), http://www.cbo.gov/ftpdocs/107xx/doc10781/11-30-Premiums.pdf; CONG. BUDGET OfF., CBO's 2011 LONG-TERM Budget OUtLOOK 25 (2011), available at http://www.cbo.gov/ftpdocs/122xx/doc12212/06-21-Long-

Term_Budget_Outlook.pdf.

43 See The Long-Term Budget Outlook (2010), supra note 10, at 61.

44 Note that the ACA's "Cadillac Tax" excise tax on the excess costs highcost health insurance plans does not begin to take effect until 2018. Jenny Gold, 
preference provided to employer-sponsored health insurance, a reduction that will grow over time. ${ }^{45}$ As of 2040 , if the ACA is fully implemented, and if its tax provisions are not suspended, postponed, or moderated, only about half of the health-care costs of those receiving employer-sponsored insurance will qualify for the current tax preference. The other half will then take the form of either employee out-of-pocket expenses or employer payments via vehicles that do not qualify for tax preference. ${ }^{46}$

This substantial excise tax on "high cost" health insurance plans is projected by the CBO to powerfully reduce the share of the federal deficit attributable to the health-care sector. ${ }^{47}$ The tax's supporters hope that it will boost economic growth in other sectors by reducing the quantity of Treasury bonds issued by the government to cover its deficit. ${ }^{48}$ Households and businesses seeking to hold bonds will then find themselves with a powerful incentive to lend money to businesses seeking to improve efficiency and profitability through greater capital intensity, and that increased productive efficiency shows itself as faster economic growth outside the health-care sector. $^{49}$ The magnitude of these economic consequences is greatly uncertain and a matter of political dispute..$^{50} \mathrm{By}$ convention, the CBO does not take these possible changes in economic growth into account in its projections.

'Cadillac' Insurance Plans Explained, Kaiser Health News (Mar. 18, 2010), http://www.kaiserhealthnews.org/Stories/2010/March/18/Cadillac-Tax-ExplainerUpdate.aspx.

${ }_{45}$ For an argument about why it is very dangerous to eliminate the tax preference for employer-sponsored insurance at least until effective universal coverage has been established, see David M. Cutler, J. Bradford DeLong \& Ann Marie Marciarille, Why Obama's Health Plan Is Better, WALl St. J., Sept. 16, 2008, at A25.

${ }^{46}$ Congressional Budget Office informal communication with authors. Thus the "Cadillac" name of the excise tax on high-cost health plans is, in the long run, a misnomer. The tax starts out as a tax on "Cadillac" health insurance plans, but as costs rise over time the tax applies to a larger and larger share of Americans. It is unclear whether the legislative coalition needed to sustain this tax over the long run will maintain itself.

${ }^{47}$ It is the driver of the CBO's projected reduction in the fifty-year fiscal gap from the 2.6 percent of GDP that it forecast in 2009 to the 0.8 percent of GDP that it forecast in 2010. See The Long-Term Budget Outlook (2009), supra note 10, at 7; THe LONG-Term Budget OutLOOK (2010), supra note 10, at 60.

48 Benjamin M. Friedman, Crowding Out or Crowding In? Economic Consequences of Financing Government Budget Deficits, 1978 BROOKINGS PAPERS ON ECON. ACTIVITY 593, 640-41 (1978).

49 See Robert M. Solow, A Contribution to the Theory of Economic Growth, 70 Q. J. ECON. 65 (1956).

50 See Alan J. Auerbach, Dynamic Scoring: An Introduction to the Issues, 95 Am. Econ. Rev. 421 (2005). 
This substantial excise tax on "high cost" health insurance plans does create some incentives for private insurers to "bend the healthcare cost curve" directly. Formerly, insurance companies that devoted additional resources to marketing rather than cost control might well have found their profits increasing as a smaller proportional margin of prices over costs was spread out over a larger customer base. Once the excise tax on "high cost" health insurance plans has gone into effect, however, failure to control costs would be heavily taxed. ${ }^{51}$ It would be more profitable to devote corporate resources to cost control rather than marketing in order to keep premiums below the cap at which the tax begins to bind.

\section{Bending the Medicare Cost Curve through the IPAB}

But the major projected bending of the health-care cost curve comes elsewhere in the ACA. The individual mandate prevents insurance companies from charging some households higher premiums while inducing other households to "go naked" without health insurance, to boost insurer profitability via adverse selection. ${ }^{52}$ Such business practices come at the price of very high administrative costs. The ACA will eliminate them. ${ }^{53}$ This will bend the cost curve as far as the private insurance market is concerned.

But, more importantly, the ACA through the IPAB is intended, and projected, to alter Medicare. The IPAB's first major task is to alter the process by which Medicare sets reimbursement rates. Thus, through the IPAB, the ACA is an experiment in binding ourselves to

51 If, indeed, the failure to control costs is the source of variation in health plan premiums. There is some evidence that only some of the variation in cost of family coverage can be explained by actuarial value of the plan. Jon Gabel et al., Taxing Cadillac Health Plans May Produce Chevy Results, 29 Health Aff. 1, 5 (2010).

52 Lucian Wulsin JR. \& Adam Dougherty, California Research Bureau, CRB 09-007, Individual Mandate: A BACKGROUND RePORT 3-4 (Apr. 2009), available at www.library.ca.gov/crb/09/09-007.pdf; Achim Wambach, Rationing Health Care and the Complementarity of Private and Public Insurance, in RAtioning in Medicine: EthicAl, Legal and PRACTICAL AsPeCts 127, 128-29 (Friedrich Breyer, Hartmut Kliemt \& Felix Thiele, eds., 2002) (discussing how rationing by price in insurance markets is both an interesting and troubling phenomenon).

53 The importance of the individual mandate to acquire coverage is as a centerpiece of any cost-growth reduction strategy. See Matthew Buettgens, et al., Why the Individual Mandate Matters: Timely Analysis of Immediate Health Policy Issues, URB. INST. 3, 6-7 (Dec. 20, 2010), http://www.urban.org/UploadedPDF/412280individual-mandate-matters.pdf (illustrating that, without an individual mandate, the ACA would still cut the number of uninsured, but by less than 50 percent). 
socially-optimal Medicare payment decisions by removing much of Congress's discretion on these matters.

The stakes are high. The long-run effects of the IPAB are projected to be enormous. This extraordinarily ambitious attempt to reform Medicare physician payments will serve as an object lesson, demonstrating the incredible tension between collective overconsumption and overspending on the one hand, and less-thansocially-optimized individual choices on the other. Consumers tend to recognize the need for rational decision making on Medicare spending allocation, ${ }^{54}$ at least until confronted with their own denial of Medicare specialty services. Specialty physicians align their interests with those of Medicare beneficiaries scared of being denied, in what Tom Daschle described as the "patient-provider pincer movement" which is designed to maximize Medicare resources for those specialists. The role of specialty physician payments in fueling Medicare cost inflation and the role of specialty physicians in shaping Medicare health-care delivery and outcomes reveal the strengths and weaknesses of trying to reform our hybrid health-care system.

\section{THE INDEPENDENT PAYMENT ADVISORY BOARD}

\section{A. Origins of the IPAB}

The IPAB is designed as an independent, executive branch board directed to recommend savings for Medicare if the per capita growth in Medicare spending exceeds defined target growth rates. ${ }^{56}$ These target growth rates are designed to bring Medicare's growth rate in line with general inflation rates.

The IPAB's scope of authority includes the mandate to issue recommendations to Congress to reduce Medicare's spending growth rate. ${ }^{57}$ These recommendations are then fast-tracked for

\footnotetext{
54 Avik Roy, NYT/CBS Poll: Plurality of Americans Favor Reduced Medicare Spending, Forbes (Apr. 22, 2011), http://www.forbes.com/sites/aroy/2011/04/22/nytcbs-poll-plurality-of-americansfavor-reduced-medicare-spending/.

55 Tom Daschle with Scott S. Greenberger \& Jeanne M. Lambrew, Critical: What We Can Do About the Health-Care Crisis 114 (2008).

56 During its first five years, if overall medical inflation does not exceed general inflation, IPAB may not issue binding proposals but it may issue advisory recommendations. Thereafter, IPAB must issue proposals if Medicare costs per beneficiary grow faster than one percentage point per year plus GDP per capita, and may not if they do not. James Ebeler et al., The Independent Payment Advisory Board: A New Approach to Controlling Medicare Spending, KAISER FAMILY Found. 6 (Apr. 2011), http://www.kff.org/medicare/upload/8150.pdf.

5742 U.S.C. $\S 1395 \mathrm{kkk}(\mathrm{b})(2)(2010)$.
} 
Congressional consideration. If Congress does not act in a timely fashion, the recommendations must be implemented by the Secretary of Health and Human Services (HHS). The IPAB's provider targets go into effect in 2020, but exclude acute care hospitals. Variously described as "recusal legislation," abnegation," 59 and "statutory entrenchment," authority is the source of its power.

Medicare is a creation of Congress and has been governed as such since its inception in 1966. The governance process for Medicare has always been intensely political. Congressional architects of America's health-care policy have long feared Congress's technical incompetence to deal with the highly complex issues of health-care spending. To help it deal with these issues, Congress thus created and has relied on its own highly-respected advisory body - the Medicare Payment Advisory Commission (MedPAC). ${ }^{61}$

MedPAC resulted from the merger of the Prospective Payment Assessment Commission and the Physician Payment Review Commission (PPRC) in 1997. ${ }^{62}$ PPRC was established in 1985 to advise Congress on ways to adapt or replace the system used to pay for physician services with a prospective payment system. Congress was the agent of physician payment reform, however, and PPRC merely offered analysis and advice on the scope and pace of implementation of physician payment system reform. ${ }^{63}$

MedPAC has maintained its credibility, but it has always been an advisory body, lacking real authority. When push comes to shove, those whom its recommendations would disadvantage have lobbied Congress, and its recommendations for Medicare system

58 Michael J. Teter, Recusal Legislating: Congress's Answer to Institutional Stalemate, 48 HARV. J. ON LEGIS. 1, 3 (2011).

59 Aaron, supra note 3, at 2377.

60 See Mathew D. McCubbins \& Daniel B. Rodriguez, Superstatutory Entrenchment: A Positive and Normative Interrogatory, 120 YALE LAW JOURNAL ONLINE 387, 396 (2011), http://yalelawjournal.org/images/pdfs/962.pdf.

61 The Medicare Payment Advisory Commission (MedPAC) is an independent Congressional agency established by the Balanced Budget Act of 1997 to advise the U.S. Congress on issues affecting the Medicare program. The Commission's statutory mandate is quite broad: in addition to advising the Congress on payments to private health plans participating in Medicare and providers in Medicare's traditional fee-for-service program, MedPAC is also tasked with analyzing access to care, quality of care, and other issues affecting Medicare. Balanced Budget Act of 1997, Pub. L. 105-33, Sec. 4022, H.R. 2015-100 (1997).

62 Ebeler et al., supra note 56, at 1, 23 n.6.

63 Thomas R. Oliver, Analysis, Advice, and Congressional Leadership: The Physician Payment Review Commission and the Politics of Medicare, 18 J. Health POL., POL'Y \& L. 113, 114 (1993). 
rationalization and cost saving have not been implemented. ${ }^{64}$

In the summer of 2009 , both Senator Jay Rockefeller and the Office of Management and Budget Director, Peter Orszag, proposed to strengthen MedPAC by making it into an executive branch commission with specific savings targets and authority, not just to make recommendations to Congress (which Congress would then ignore), but to initiate action. Their proposals became what is now the IPAB: an independent board in the executive branch, consisting of fifteen members appointed by the President with the advice and consent of the Senate. The IPAB members cannot engage in any other employment; thus they cannot be otherwise-employed members of the health policy community. Given the enemies that the IPAB's cost-cutting recommendations are likely to make in the provider and insurance communities, members of the board are not likely to be employed in the future by providers or insurers. An appointment to the IPAB is thus likely to be a career-ending, capstone position, at least for those of its members pursuing careers in health-care finance. ${ }^{65}$

The IPAB represents the latest, and strongest, iteration of an independent, expert panel dedicated to reducing the per capita rate of growth in Medicare spending. Created by the ACA as the watchdog of target growth rates for Medicare, the IPAB will spring to life in 2012. Based on the assumption that Congress and the federal administrative agencies have proven themselves too accommodating to the provider, payor, and consumer forces that propel an everincreasing Medicare spending growth rate, the IPAB is designed to limit the growth of Medicare spending as well as improve the governance structure for Medicare. ${ }^{66}$ Demonstrating what Henry Aaron has called the "legislative statesmanship" of "selfabnegation," ${ }^{67}$ Congress has insulated the IPAB from legislative intrusiveness $^{68}$ as well as from constituent influence. ${ }^{69}$

${ }^{64}$ See Ebeler, supra note 56, at 3.

65 The simultaneous requirements of substantive expertise and restrictions on other income-producing activity may help to account for the lack of nominees to date. Alternatively, it may make no sense to even attempt an appointment until the fate of the ACA is resolved at the Supreme Court. Jennifer Haberkorn, Health Policy Brief: The Independent Payment Advisory Board, HeAlth AfF. 2 (Dec. 2011), http://healthaffairs.org/healthpolicybriefs/brief_pdfs/healthpolicybrief_59.pdf.

${ }^{66} I d$. at 1 .

67 Aaron, supra note 3, at 2377.

68 See id. at 2377-78.

69 Steve Benen, The Independent Advisory Board Comes Under Fire, WASH.

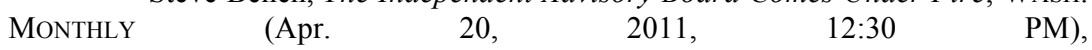
http://www.washingtonmonthly.com/archives/individual/2011_04/029035.php. 
According to David Nather of Politico, "IPAB has become a huge lightning rod." 70 Already, there are calls to strengthen the role of the $\mathrm{IPAB}^{71}$ and calls to repeal it. ${ }^{72}$ But it is a Medicare reform lightning rod for a variety of reasons. The rhetoric of the IPAB's supporters and detractors focuses on how it is designed to work, who will serve, and whether it will be effective.

\section{B. The Operation of IPAB}

The ACA sets target growth rates for Medicare spending beginning in $2014 .^{73}$ These growth rate targets serve as triggers for IPAB's authority to submit specific Medicare savings recommendations to Congress - but they are more than mere "recommendations" that Congress will then ignore. Congress must respond or else the proposals automatically go into effect. ${ }^{74}$

By the force of default implementation, ${ }^{75}$ the IPAB's assignment is clearly to tame Medicare outpatient spending growth, ${ }^{76}$ and bring it

70 David Nather, Medicare Cost-Cutting Job Could Be Worst in D.C., PolitiCO.COM (May 14, 2011), https:// http://www.politico.com/news/stories/0511/54952.html.

71 Nat'l Comm'n on Fiscal Resp. \& Reform, The Moment of Truth 36 (Dec. 2010), http://www.usatoday.com/news/_photos/2010/12/01/TheMomentofTruth.pdf; Remarks by the President on Fiscal Policy, WhiteHouse.gov (Apr. 13, 2011), http://www.whitehouse.gov/the-press-office/2011/04/13/remarks-president-fiscalpolicy.

72 Cal. Health Care Found., Medicare Cost-Cutting Board Faces Mounting Opposition in Congress, CAL. Healthline (Apr. 18, 2011), http://www.californiahealthline.org/articles/2011/4/18/medicare-costcutting-board-

faces-mounting-opposition-in-congress.aspx (citing Julian Pecquet, House Democrats' Defections Threaten Obama's Medicare Advisory Board, Healthwatch (Apr. 15, 2011, 11:49 AM), http://thehill.com/blogs/healthwatch/medicare/156343democrats-defections-threaten-obamas-medicare-savings-gambit).

73 For 2015 through 2019, Medicare spending per capita's target is the average of general and medical inflation. Brad Vaida, The IPAB: How Could It Change Medicare?, KAISER HEALTH News (May 8, 2008), http://www.kaiserhealthnews.org/Stories/2011/May/09/ipab-faq.aspx. For 2020 and later, the target is the gross domestic product plus one percentage point, though the President has floated a proposal to tighten IPAB's target in later years to GDP plus 0.5 percentage point. Id.

7442 U.S.C. $\S 1395 \mathrm{kkk}(\mathrm{b})(3)$ (2010).

75 See Ebeler, supra note 56, at 9.

76 ACA's exclusions of inpatient and outpatient acute care hospital services, inpatient rehabilitation, psychiatric facilities, long-term care hospitals, and hospices from IPAB scrutiny until 2020 leaves the focus of immediate IPAB scrutiny on Medicare Advantage, Medicare Part D, skilled nursing facilities, home health, dialysis, ambulance, ambulatory surgical center services, and durable medical equipment. $I d$. at 10 . 
in line with general inflation rates while also maintaining or enhancing Medicare beneficiary access to quality care. The goal is not to cap Medicare's spending growth rate so as to align it with general inflation rates, but rather right-size it relative to other sectors of the economy. ${ }^{77}$

For 2015 to 2019, the target growth rate for Medicare spending per capita is the average of overall inflation and medical inflation. ${ }^{78}$ Thereafter the target is one percentage point more than the per capita GDP growth rate. Every year, the Centers for Medicare and Medicaid Services (CMS) Actuary must determine whether the Medicare growth rate is exceeding the target growth rate. If it is, the IPAB is required to develop and submit a proposal to bring Medicare spending growth below the target rate. ${ }^{79}$

The IPAB must submit its annual proposal for reducing Medicare spending growth by January 15 . If it fails to do so, the Secretary of HHS must submit a proposal meeting the requirements by January 25. In either event, the Secretary must transmit and MedPAC must comment on the IPAB proposal by March 1, after which the proposal is considered by Congress. ${ }^{80}$ In the event Congress does not act on the proposal, the Secretary of HHS is required to implement the recommendations for the subsequent fiscal year. ${ }^{81}$

The tension between the IPAB's obligation to monitor and master Medicare's spending growth rate and its obligation to maintain or

77 Id. at 3 .

78 Id. at 6 .

79 A technical note: ACA does not strictly require IPAB to recommend proposals to keep Medicare spending below target growth rates in all circumstances. Rather, it requires IPAB to reduce Medicare spending by the amount of the excess over the target only up to a specified percentage maximum that is unlikely to be reached. The fear is that should costs explode for some unknown reason, IPAB would then be forced by law into draconian and counterproductive economies. The Congressional architects of ACA seek to avoid that eventuality.

${ }^{80}$ There has been very little discussion of the fact that the legislative language appears to grant the Secretary of Health and Human Services the powers and authority of the IPAB in the event that the IPAB itself deadlocks and fails to carry out its mission. The powers that Congress may delegate to an independent board are different than the powers Congress may delegate to a cabinet officer.

${ }^{81}$ IPAB is prohibited from: (1) increasing Medicare cost sharing or premiums; (2) rationing health care; or (3) restricting benefits or modifying eligibility criteria. It cannot reduce payment rates for providers and suppliers below levels already specified elsewhere in ACA until 2020. In its first five years, therefore, IPAB is likely to focus on aspects of Medicare like durable medical equipment, dialysis, prescription drugs, Medicare Advantage, and home health. The savings that the CBO expects from the IPAB up until 2020 are thus not overwhelmingly large. Afterwards, however, the potential for major reforms greatly increases. See Ebeler, supra note 56, at $7-8,10$. 
enhance beneficiary services is framed by the ACA's limits on the IPAB's authority. The IPAB may not recommend rationing of health care, raising Medicare beneficiary premiums, cost sharing, or modifying eligibility criteria. The joke that the IPAB is an acronym for "Death Panel" illustrates the concern and confusion over the IPAB's statutory and regulatory role. ${ }^{82}$ The IPAB, as laid out in the ACA, is constrained in its choice of weapons to control Medicare spending growth. ${ }^{83}$ In addition, Medicare specifically withholds the power to regulate the practice of medicine from the federal government. ${ }^{84}$ All of this raises the question of whether the IPAB is too strong or not strong enough to accomplish its goal of bending the cost curve on Medicare cost inflation.

Congress must consider the IPAB's proposals under special expedited procedures. ${ }^{85}$ The committees ${ }^{86}$ and the full House and Senate cannot consider any amendment that would change or repeal the Board's recommendations unless those changes meet the same fiscal targets that the IPAB met (however, three-fifths of Senators can override this restriction). The Senate must vote on the proposal by the end of no more than thirty legislative hours. ${ }^{87}$ The Senate must vote on any conference report or amendment by the end of no more than ten legislative hours. ${ }^{88}$

The ACA and the economic realities of Medicare spending have thus set the stage for the IPAB's first major assignment. Its initial agenda cannot include Medicare inpatient services. Its agenda is

82 See, e.g. David Catron, IPAB is an Acronym for 'Death Panel', AMER. SPECTATOR (Apr. 22, 2011, 6:09 AM), http://spectator.org/archives/2011/04/22/ipabis-an-acronym-for-death-p.

83 See supra note 79.

84 Social Security Amendments of 1965, Pub. L. No. 89-97, § 1801, 79 Stat. 286, 291 (1965).

8542 U.S.C. $\S 1395 \mathrm{kkk}(\mathrm{d})(4)(2010)$.

86 "When introduced in the House, an implementing bill is to be referred to House Committees on Energy and Commerce and on Ways and Means. In the Senate, the measure is to be referred to the Committee on Finance." "Fast Track" Parliamentary Procedures Relating to the Independent Payment Advisory Board (IPAB): Hearing Before the H. Comm. on Energy and Commerce Subcomm. on Health, 112th Cong. 11 (2011) (statement of Christopher M. Davis, Analyst on Congress and the Legislative Process, Congressional Research Service), available at http://republicans.energycommerce.house.gov/Media/file/Hearings/Health/071311/Da vis.pdf.

87 The thirty-hour decision deadline is tolled by the delivery of IPAB's formal recommendations from HHS to Congress. Id. at 13-14.

${ }^{88}$ Congress has reserved to itself the opportunity for a one-time fast-track joint resolution to dissolve IPAB in January of 2017. Dissolving IPAB via fast-track requires: (a) passage by August 15, 2017; and (b) the votes of three-fifths of members in the House and Senate. Id. at 9, 16-19. 
limited to payments reform. Given that, the intersection of Medicare outpatient services and payment system reform is found at the Medicare Physician Fee Schedule (MPFS). This makes it likely that the IPAB, at its launch, will focus on the MPFS. The key question is how the IPAB might wield its power to tame Medicare spending growth.

\section{THE IPAB AND THE MediCARE PHYSICIAN FeE SCHEDULE}

\section{A. The Importance of the Medicare Physician Fee Schedule}

The architects of the ACA designed the IPAB to undertake reforming MPFS as a stepping stone to overall value-based payment reform. Migration of the health-care financing system to value-based payment will be neither easy nor quick. ${ }^{89}$ Value-based payment systems in the future are likely to build on the current MPFS; the current reimbursement practices are the most obvious place to start. It is one of the few places where the stakes are large enough to bend the health-care inflation cost curve. The ACA proposes to slow Medicare spending growth through a comprehensive implementation of Medicare's prospective payment system in the realm of physician services through the efforts of the IPAB. As Gerard Anderson et al. observed, "[a]lthough the huge federal Medicare program . . . possess[es] some monopsonistic purchasing power . . . the highly fragmented buy side of the U.S. health system is relatively weak." ${ }^{90}$ The IPAB's assignment is to harness some of the monopsonistic purchasing power of the federal Medicare program by reworking physician payment standards. What role might the IPAB might play in the near-term revision of the MPFS? What limits are there to the IPAB's capacity to rapidly take action to bend the cost curve on health-care inflation?

Curtailing Medicare spending growth is not a novel goal. But past efforts to contain Medicare spending growth on physician services have been notably less successful than, for example, efforts to

89 Robert A. Berenson, Out of Whack: Pricing Distortions in the Medicare Physician Fee Schedule, Nat'L Inst. For Health CARe Mgmt. Found. 1 (Sept. 2010), http://nihcm.org/pdf/NIHCM-EV-Berenson_FINAL.pdf.

${ }^{90}$ Gerard F. Anderson et al., It's the Prices, Stupid: Why the United States Is So Different from Other Countries, 22 HeAlth AfF. 89, 102 (2003). 
contain Medicare spending growth for inpatient hospital services. ${ }^{91}$

Medicare operates on a system of administered pricing that, with varying degrees of success, has most recently attempted to slow spending growth by the use of prospective payment systems. Although much-maligned, Medicare's prospective payment systems have had some success in slowing Medicare spending growth for inpatient services, ${ }^{92}$ transitory success in slowing Medicare spending growth for post-acute care, ${ }^{93}$ and little success in slowing Medicare spending growth for physician services. ${ }^{94}$ It is worth understanding why the effectiveness of Medicare's prospective payment system has been particularly blunted in the areas of physician services. The question is complex, as is the answer. But it is worth asking because it is Medicare's prospective payment system that has been most effective at slowing Medicare spending growth - not managed care, not changes in cost-sharing, and not industry-sponsored voluntary efforts. ${ }^{95}$

Why are Medicare physician services the lynchpin to slowing Medicare spending growth? First, a large percentage of health costs are within the discretionary control of physicians, ${ }^{96}$ and the average primary care physician's discretionary referrals display tremendous geographic and practice context variance. ${ }^{97}$ If Medicare does not control the volume of spending physicians direct, Medicare will find it difficult to tame costs. ${ }^{98}$ Second, despite a substantial body of empirical analysis on the control physicians exercise over discretionary health-care spending, Medicare physician payments have not been trending downward. ${ }^{99}$ Finally, the failure to give

${ }^{91}$ Chapin White, Why Did Medicare Spending Growth Slow Down?, 27 Health AfF. 793, 795 (2008).

${ }^{92}$ Id. at $795-96$.

${ }^{93}$ Id. at $796-97$.

${ }^{94}$ Id.

95 Id. at 793; Stuart Guterman et al., Using Medicare Payment Policy to Transform the Health System: A Framework for Improving Performance, 28 Health AFF. w239 (2009).

96 Brenda Sirovich, et al, Discretionary Decision Making by Primary Care Physicians and the Cost of U. S. Health Care, 27 Health AfF. 813, 814 (2008).

97 Howard Brody, Medicine's Ethical Responsibility for Health Care Reform-The Top Five List, 362 NEw ENG. J. MED. 283, 284 (2010).

98 Austin Frakt, Health Care Cost Control is Hard, and Humbling, INCIDENTAL ECONOMIST (Nov. 7, 2010, 7:00 AM), http://theincidentaleconomist.com/wordpress/health-care-cost-control-is-hard-andhumbling/.

99 Uwe Reinhardt, The Annual Drama of the 'Doc Fix,' ECONOMIX: N.Y. $\begin{array}{llll}\text { Times BLOG } & \text { (Dec. 2010, 6:00AM), }\end{array}$ http://economix.blogs.nytimes.com/2010/12/17/the-annual-drama-of-the-doc-fix /. 
physicians who participate in Medicare ${ }^{100}$ a financial and performance stake in efforts to control Medicare spending has left those most able to "bend the cost curve" on Medicare spending growth outside the circle of interest and power capable of exerting this control. ${ }^{101}$

\section{B. What Is the Problem to Which the IPAB Is the Solution?}

The IPAB is designed as an independent fifteen-member board of the executive branch. The IPAB's members, most importantly, are to be full-time federal employees excluded from outside employment, and paid the salary of senior executives in the federal government. ${ }^{102}$ Each member will be a presidential appointee with relevant expertise in health care, health economics, health research and technology, health insurance, and employer sponsors of health insurance. The President is required to seek the advice and consent of various Congressional leaders in making twelve of these appointments, but retains exclusive authority over three of these six year appointments. $^{103}$

Given the duration of the exclusive service requirement, service on the IPAB might have to be seen as a career capstone project. Limiting likely service on the IPAB to those at the end of their career narrows the field of potential appointees. ${ }^{104}$

The purpose of excluding outside employment is obviously to avoid any conflict of interest, though why prior service and retirement packages comprised of investment holdings in the entity are not a

100 These individuals are properly referred to as physicians who "accept Medicare assignment." 42 C.F.R. $\S 414.50$ (b)(2) (2009).

101 See Steve M. Shortell, Bending the Cost Curve: A Critical Component of Health Care Reform, 302 JAMA 1223, 1223 (2009).

${ }^{102}$ The salary of an IPAB member in 2011 is $\$ 165,300$. Rates of Basic Pay for the Executive Schedule (EX): Rates Frozen at 2010 Levels: Effective January 2011, U.S. OFF. PERSONNEL MGMT. (Jan. 2011), http://www.opm.gov/oca/11tables/pdf/ex.pdf.

103 Memorandum from Christopher M. Davis, Analyst on Congress and the Legislative Process \& Henry B. Hogue, Analyst in American National Government to Senator Tom Coburn (Mar. 18, 2011), available at http://coburn.senate.gov/public//index.cfm?a=Files.Serve\&File_id=3fe9e198-fe6c4fb2-9777-88c69ff72356.

104 Two witnesses at a July 2011 "House Energy and Commerce Health Subcommittee session-American Enterprise Institute fellow Scott Gottlieb and Georgetown Public Policy Institute professor Judith Feder"-indicated they had discussed IPAB appointment with the Obama administration. The Focus on Bringing Down IPAB, KAISER HEALTH NEWS (July 14, 2011), http://www.kaiserhealthnews.org/Daily-Reports/2011/July/14/ipab.aspx?p=1. 
problem is a mystery. The purpose of the lengthy term of service is to send a strong message about the lack of revolving door opportunities for the IPAB appointees. Willingness to serve (or lack thereof) under such stringent limitations will only become evident as the program is implemented.

\section{IPAB: Can It Work?}

Because Medicare physician payments are so huge, it is tempting to assume they are too large. But do we actually overpay for Medicare physician services? To answer this we need to understand how Medicare pays for physician services, how commercial insurance pays for physician services, and the perverse relationship between the two.

\section{The Sustainable Growth Rate Formula}

Earlier attempts have been made to tether the growth of Medicare physician payments to GDP growth. Dating from the early 1990s, the "much hated" 105 sustainable growth rate (SGR) formula has hovered over Medicare physician payment for decades. The SGR formula requires cuts in Medicare reimbursements if total Medicare payments to physicians exceed GDP growth by a certain amount.

However, SGR has never been implemented because Congress is, and has been, unwilling to lower fees for all services. ${ }^{106}$ The attraction of adjusting physician payments "with a scalpel" 107 is that some physician services are overpaid while others do not even cover their costs. The challenge is to reduce the overvalued, raise the undervalued, and do it all with a budget neutral outcome. ${ }^{108}$ To attempt to gain the expertise necessary to accomplish this task, Congress established MedPAC.

105 Maggie Mahar, Comparing the Fiscal Commission's Proposals to the Accountable Care Act, HeAlth BeAt Blog (Dec. 2, 2010), http://www.healthbeatblog.com/2010/12/comparing-the-fiscal-commissionsproposals-to-the-accountable-care-act.html.

106 Id.

${ }^{107} I d$.

108 The relationship between Medicare payment system reform and the institutionalization of comparative effectiveness concerns into Medicare has made IPAB a controversial entity. IPAB's broader portfolio of responsibilities raises the question of whether IPAB represent the introduction of command and control regulation into health care, where it is rarely found. If the broader scope of responsibility makes IPAB a comparative effectiveness agency as much as a Medicare payment system reform entity, ought it not be explicitly acknowledged as such? 
MedPAC is and always has been an exclusively advisory body. ${ }^{109}$ Established by the Balanced Budget Act of 1997, MedPAC was designed to advise Congress on fee-for-service Medicare payment systems in addition to analyzing access and quality of care issues. MedPAC has seventeen members who serve three-year renewable terms on a part time basis. They are appointed by the Comptroller General. ${ }^{110}$ MedPAC issues two reports-March and June each year-to publicize its recommendations. ${ }^{111}$

\section{Will IPAB Do Better than MedPAC?}

In contrast to the "oft-ignored" MedPAC, ${ }^{112}$ the IPAB is designed to demand Congressional attention. Its recommendations become law unless the House and the Senate adopt resolutions to block them. The default impact on the Medicare entitlement program will empower IPAB. Rather than proposing alternatives to the Medicare fee-forservice status quo, IPAB will drive the dimensions of the status quo. Congress must take affirmative action to derail IPAB's power, if it wishes.

MedPAC was not abolished by the ACA, however. Nor is the IPAB going to be a super-MedPAC. ${ }^{113}$ MedPAC's mandate to review the global health-care system is not replicated in the IPAB. MedPAC also has substantial expertise to offer. MedPAC's staff and expertise are so valued, in fact, that MedPAC lives on under the ACA as the Congressional advisory body that will review the IPAB's

109 Senator Jay Rockefeller introduced legislation to transform MedPAC into an independent executive agency, modeled on the Federal Reserve Board, in May of 2009. Other failed proposals, including one from Senator Tom Daschle, were to create a health Fed designed to reach far beyond Medicare. Laura Yao, MedPAC is Primed for Bigger Role in Health-Care Overhaul, WALl ST. J. HeAlth Blog (June 3, 2009, 4:54 PM), http://blogs.wsj.com/health/2009/06/03/medpac-is-primed-forbigger-role-in-health-care-overhaul.

${ }^{110}$ Medicare Payment Advisory Commission (MedPAC), U.S. Gov'T ACCOUNTABILITY OFF., http://www.gao.gov/about/hcac/medpac.html (last visited Jan. $3,2012)$.

11 See Documents, MEDPAC, http://www.medpac.gov/documents.cfm (last visited Nov. 8, 2011) (select "Reports" in the "Document Type" field), for these reports.

112 So the Commonwealth Fund's health policy newsletter called it: John Reichard, Washington Health Policy Week in Review the Medicare Payment Advisory Commission: Will it Matter Anymore?, Commonwealth Fund (May 14, 2010), http://www.commonwealthfund.org/Content/Newsletters/Washington-Health-Policyin-Review/2010/May/May-17-2010/The-Medicare-Payment-Advisory-CommissionWill-It-Matter-Anymore.aspx

113 Robert A. Berenson, Implementing Health Care Reform-Why Medicare Matters, 363 New EnG. J. Med. 101, 102 (2010). 
recommendations. Whether or not the two entities will work in tandem or at odds, for the foreseeable future they will co-exist, one with the default authority to set Medicare payment policy and the other with the mandate to advise Congress as to the wisdom of these policy proposals. It is ironic that MedPAC's most forceful role yet may be as Congressional advisor on the IPAB. ${ }^{114}$

\section{IPAB's Governance}

IPAB's governance and policy structure can be seen as a hybrid of three previous attempts by Congress to tie itself to the mast and so reduce political interference with extremely knotty and important, but ultimately technocratic questions. These attempts resulted in the creation of the Federal Reserve Board (Fed), the Securities and Exchange Commission (SEC), and the Defense Base Closure and Realignment Commission (BRAC). ${ }^{115}$

BRAC's process began with published selection criteria for military base closures, Secretary of Defense recommendations to the independent commission, commission study (including public input) of these recommendations, and ultimately, commission recommendations to the President. Like IPAB, Congress had a brief window of opportunity to act on the commission's report (on an all or nothing basis) before the commission's realignment and closure recommendations became law. ${ }^{116}$ Although the IPAB's scope of authority is limited and based on a staged rollout, its decision-making structure is similarly designed to be insulated from external influence.

The insight that "[e]veryone wants to lower costs until someone tries to lower costs" $" 117$ could not be more applicable to the IPAB or to Medicare reform in general. Whether the IPAB can deliver what has been described as the framework for "learning to say no" "will be its biggest challenge. Although it is often thought that Medicare beneficiaries most need to learn this lesson, ${ }^{119}$ it is likely the IPAB

114 Reichard, supra note 112.

115 BRAC was created for a fixed term by the Defense Base Closure and Realignment Act of 1990. Defense Base Closure \& Realignment Comm'n, Final REPORT TO THE PRESIDENT 305 (2005), available at http://www.brac.gov/docs/final/Chap2IssuesforFurtherConsideration.pdf.

11642 U.S.C. $\S 1395 \mathrm{kkk}(\mathrm{b})(3)$ (2010).

117 Benen, supra note 69.

118 Paul Krugman, Choices Must Be Made, N.Y. Times Blog (Apr. 20, 2011, 11:37 AM), http://krugman.blogs.nytimes.com/2011/04/20/choices-must-be-made/.

${ }_{119}$ Demand driven overconsumption by Medicare beneficiaries is traced to the moral hazard inherent in all insurance coverage and amplified by the substantial impact of Medicare secondary insurance ("Medigap"). See David M. Zimmer, The 
will have to deliver the message first to Medicare providers.

\section{The IPAB's INITIAL Principle ASSIGNMENT}

\section{A. Relative Value Units}

It is significant that the scope of the IPAB's authority and the staging of its rollout combine to focus its first task on outpatient physician services. Physician services billed to Part B account for about 13 percent of all Medicare spending. ${ }^{120}$ Medicare uses a physician fee schedule to determine physician payment rates. Values are assigned based on the amount of work required for a listed service, the expenses related to maintaining a practice, ${ }^{121}$ and liability insurance costs.

Payments are updated yearly under the SGR formula, designed to keep Medicare spending growth "consistent with growth in the national economy." 122 The ACA establishes specific target growth rates for Medicare and appoints the IPAB the guardian of those goals. ${ }^{123}$ Just as physician conduct defeated the promise of the Resource-Based Relative Value Scale (RBRVS), discussed below, by raising the volume of services provided, ${ }^{124}$ Medicare Volume Performance Standards (VPS) have attempted to address increased Medicare physician service volumes, as to both frequency and intensity of services. Physician payment system reform has repeatedly and sequentially vacillated between a focus on expenditures and a focus on costs without acknowledging the relationship between the two. ${ }^{125}$

Relative weights or relative value units (RVUs) are the core of the MPFS. RVUs are designed to account for the relative costliness of resources used to provide each service and reflect the relative levels of

Relationship Between Medicare Supplemental Insurance and Health-Care Spending: Selection Across Multiple Dimensions, 38 E. ECON. J. 118 (2012).

120 Physician Services Payment System, MedPAC 1 (Oct. 2010), www.medpac.gov/documents/MedPAC_Payment_Basics_10_Physician.pdf.

121 Geographic adjustments reflecting regional differences in wages, rent and other costs are themselves controversial. Robert Pear, Report Finds Inequities in Payments for Medicare, N.Y. Times, June 2, 2011, at A18.

${ }^{122}$ Congress has regularly specified an update outside of the SGR formula. Physician Services Payment System, supra note 120, at 1.

123 Timothy Stoltzfus Jost, The Independent Payment Advisory Board, FresHTHINKING 2.0 MEDICARE Workshop 1 (May 3-4, 2010), available at http://www.fresh-thinking.org/publications/IPAB_Jost.pdf.

${ }^{124}$ William C. Hsiao, et al., Assessing the Implementation of PhysicianPayment Reform, 328 New ENG. J. MED. 928, 932-33 (1993).

125 Jonathan Oberlander, The Political Life OF Medicare 133 (2003). 
time, effort, skill, and stress involved. ${ }^{126}$ Physician services, in short, have been distilled to these components: time, effort, skill, and stress. The origins of assigning relative weights to physician effort and skill trace back to the invention of RBRVS. Harvard Medical School Professor William Hsiao rationalized the most common Medicare physician services in a kind of medical time study, based on his understanding of the time, effort, skill and stress involved in these services in 1992. ${ }^{127}$ These relative weights are updated at least every five years. As reported by MedPAC, "in completing its review, CMS receives advice from a group of physicians and other professionals sponsored by the AMA and physician specialty societies."128

William Hsiao's legacy is a system that systematically undervalues cognitive services, and systematically overvalues medical procedures. $^{129}$ As a result, specialty physician services enjoy continued dominance in the delivery and budget of the Medicare program.

At this point, one would expect an authorial team including an economist to sneer in Hayekian fashion at thumb-fingered government regulatory bureaucracies. Government is one-size fits all and cannot process detailed information; private actors in markets are more efficient and flexible, economists might say. They must, under pressure of competition, create better ways of classifying expenditures and reimbursing providers than the rigid command-and-control accounting system of Dr. William Hsiao. ${ }^{130}$

If the economist co-author were to say this, however, he would be wrong. It is a fact that the bulk of private insurers use Dr. Hsiao's work and the RVS as a baseline against which to make their own

126 William C. Hsiao, et al., Estimating Physicians' Work for a ResourceBased Relative-Value Scale, 319 New Eng. J. Med. 835, 835-36 (1988); Physician Services Payment System: Payment Basics, MedPAC 1 (Oct. 2009), http://www.medpac.gov/documents/MedPAC_Payment_Basics_09_Physician.pdf.

${ }_{127}$ Hsiao, supra note 126, at 835-36, 840. William Hsiao's seminar RBRVS research was conducted in 1985, published in 1988, adopted into the Medicare payment schedule in 1989, and took effect on January 1, 1992. History of the RBRVS, AM. MED. Ass'N, http://www.ama-assn.org/ama/pub/physician-resources/solutionsmanaging-your-practice/coding-billing-insurance/medicare/the-resource-basedrelative-value-scale/history-of-rbrvs.page (last visited Jan. 8, 2012).

128 Physician Services Payment System, supra note 120, at 3.

129 Darshak Sanghavi, The Fix Is In: The Hidden Public-Private Cartels that Sets Health Care Prices, Slate MAg. (Sept. 2, 2009), http://www.slate.com/id/2227082/.

130 See, most famously, F. A. Hayek, The Use of Knowledge in Society, 35 Amer. Econ. Rev. 519 (1945). 
pricing and reimbursement decisions. ${ }^{131}$ The market cannot magically create information out of thin air. It has to be created by somebody, somewhere - and that somebody is Medicare. As the largest paying unit in America's health-care system, it would be surprising if Medicare did not turn out to be both the price and the administrative process leader whose judgments are taken as a baseline that other purchasers use in making their own pricing and reimbursement decisions. ${ }^{132}$

\section{B. The RVS Update Committee}

The AMA and several national medical specialty societies created the AMA/Specialty Society RVS Update Committee (RUC) to inject its expertise into the RBRVS payment system review process. ${ }^{133}$ But it has not been without controversy. MedPAC's March 2010 report to Congress recommended limiting Medicare's unit prices, ${ }^{134}$ and the ACA requires HHS to periodically review these relative codes with special attention to potentially "mis-valued" codes. ${ }^{135}$ This is because CMS has shown tremendous deference to RUC recommendations. ${ }^{136}$ RUC's recommendations are accepted by CMS 94 percent of the time. ${ }^{137}$ Anything that disturbs the order of this will be worldview changing.

CMS's deference to RUC does not come after a long experiment with command and control regulation tempered by the acknowledgment that self-regulation may prove the wiser course. The RUC has been captured since its inception. ${ }^{138}$ If capture represents a

131 Jon Harris-Shapiro and Marcia S. Greenstein, RBRVS-1999 Update, 26 J. Health CARe Fin. 48, 48 (1999).

${ }^{132}$ Henry G. Dove, Use of the Resource-Based Relative Value Scale for Private Insurers, 13 HeALTH AFF. 193, 198 (1994).

133 Barbara Levy, The RUC-Providing Valuable Expertise to the Medicare Program for Twenty Years, KAISER HeAlth News (Mar. 28, 2011), http://www.kaiserhealthnews.org/Columns/2011/March/032811levy.aspx.

${ }^{134}$ MedPAC, Report to the Congress: Medicare Payment Policy xiii (2010), available at $\mathrm{www} . m e d p a c . g o v / d o c u m e n t s / M a r 10 \_$EntireReport.pdf.

13542 U.S.C.A. § 1395w-4(c)(2)(K)(i)(II) (2010).

136 Gina Shaw, Is the RUC Broken?, NeURology TODAY, Nov. 18, 2010, at $20,20$.

137 Joe Eaton, Powerful Medical Insiders Make Determinations on Medicare, $\begin{array}{lllll}\text { CutTing EDGE News } & \text { (Nov. }\end{array}$ http://www.thecuttingedgenews.com/index.php? article $=21768$ \&pageid $=22$ \&pagename $=$ Investigation .

138 Am. Med. Ass'N, The RUC: ReCEnt ACtivities to Improve the Valuation of Primary Care Services, Executive Summary (Aug. 2008), available at http://www.ama-assn.org/resources/doc/rbrvs/rucbotreport.pdf ("The original 
regulated industry dominating the creation and enforcement of a regulation, ${ }^{139}$ then the establishment and operation of RUC embodies capture of a more nuanced type. Here we have capture of the outpatient physician payment schedule by one group of providers to the exclusion of others. Yet RUC is a poster child for how secret, unmonitored self-regulation does not manifest the upside of capture, where voluntary compliance improves regulatory outcomes. ${ }^{140}$

It has been observed that "[a]lthough some consider the volumegenerating incentives of current payment systems so perverse that they would not spend much time correcting existing mispriced values ... it will be necessary to correct mispricing and other flaws in existing fee-for-service payment systems in order to ultimately dismantle them." 141 Indeed, if we do not assess and correct for the contribution of overvalued services to Medicare's cost-inflation, we run the risk of building the same defects into any future Medicare payment and delivery system. The kind of morphic resonance ${ }^{142}$ that leads us to design a system that systematically undervalues the services we should value the most will require a thorough morphology to avoid replication. IPAB's assignment to consider RUC's contribution to medical inflation, as a result, is both medically and politically freighted. ${ }^{143}$

\section{Why Medicare Physician Reimbursement Relative Value Units Should Matter to IPAB}

Medicare's relative value scale is the foundation of the MPFS. The roughly 7,000 RVUs in Medicare's relative value scale are supposed to reflect true relative practices costs. ${ }^{144}$ Rapid advances in

\footnotetext{
intent was to include all major specialties, primarily defined as the 24 Member Boards of the American Board of Medical Specialties.").

139 Dieter Helm, Regulatory Reform, Capture, and the Regulatory Burden, 22 OXFORD REV. ECON. POL'y 169, 174 (2006).

140 Dorit R. Reiss, The Benefits of Capture 6-12, $45-46$ (U.C. Hastings College of Law Working Paper Series, 2011) available at http://papers.ssrn.com/sol3/papers.cfm?abstract_id=1904023.

141 Berenson, supra note 113 , at 103.

142 See Barbara S. Levy, AMA/Specialty Society RVS Update Committee (RUC), NAT'L HEAlth POL'y Forum (Mar. 5, 2010), http://www.nhpf.org/library/handouts/Levy.slides_03-05-10.pdf.

143 See Berenson, supra note 113, at 102.

144 Uwe E. Reinhardt, The Little-Known Decision-Makers for Medicare Physicians Fees, Economix: N.Y. TIMES BLOG (Dec. 10, 2010), http://economix.blogs.nytimes.com/2010/12/10/the-little-known-decision-makers-formedicare-physicans-fees.
} 
medical technology require RVU adjustments over time. ${ }^{145}$ The RBRVS determines prices based on physician work (52 percent), practice expense (44 percent), and malpractice expense ( 4 percent). Although all of the RBRVS components are contentious, ${ }^{146} \mathrm{CMS}$ relies heavily on RUC to assist it with this task. ${ }^{147}$ RUC is a group of twenty-nine physicians drawn from a variety of medical specialties. Specifically, RUC is composed of a chair, six AMA committee representatives, and twenty-three members at large. ${ }^{148}$

When RUC was first formed, representatives were requested from each of the specialties within the American Board of Medical Specialties, except for neurology. ${ }^{149}$ Medical specialties have evolved significantly since that time. Although neurology is now represented on RUC, geriatricians, oncologists, and gastroenterologists are now excluded from RUC seats. Neurology's later addition is consistent with neurology's transformation from a patient-oriented to a procedure-oriented focus. ${ }^{150}$ As each specialty delegate's vote is limited to one equally weighted seat, the valuation of the work of all physicians is set by physicians almost entirely outside of the relevant specialty. ${ }^{151}$ Inevitably, patient-oriented services are systematically devalued. The vast majority of voting status representatives on RUC are procedural- or surgery-focused specialties. ${ }^{152}$ Medicare requires

145 Id.

146 Practice expenses, for example, are based on residential and not professional office rental rates. U.S. Gov'T ACCOUNTABILITy OfFICE, GAO-05-119, Medicare Physician Fees: Geographic Adjustment Indices are Valid in Design but Data and Methods Need Refinement 18 (2005), available at http://www.gpo.gov/fdsys/pkg/GAOREPORTS-GAO-05-119/pdf/GAOREPORTSGAO-05-119.pdf.

147 RUC was established by the AMA in 1991. Am. Med. Ass'n, Report 14 of the BoARd of Trustees: The RUC: Recent Activities to Improve the VAluation of Primary CARE SERvices 9 (Aug. 2008), available at http://www.amaassn.org/resources/doc/rbrvs/rucbotreport.pdf.

148 Robert Lowes, Lawsuit Targets Medicare Pay "Bias” Toward Specialists, MEDSCAPE News TODAY (Aug. 10, 2011), http://www.medscape.com/viewarticle/747847.

149 Shaw, supra note 136, at 20.

150 See Stephen G. Waxman, From Neuroscience to Neurology: Neuroscience, Molecular Medicine and the Therapeutic Transformation of NEUROLOGY vii (2005).

151 Medical specialties with RUC voting status include: anesthesiology, cardiology, colon and rectal surgery, dermatology, emergency medicine, family medicine, general surgery, internal medicine, nephrology, neurology, neurosurgery, obstetrics/gynecology, ophthalmology, orthopedic surgery, otolaryngology, pathology, pediatrics, plastic surgery, pulmonary medicine, psychiatry, radiology, thoracic surgery, and urology. Shaw, supra note 136 , at 21.

${ }^{152}$ Id. at 20. 
that all RUC relative value adjustments be budget-neutral as well. ${ }^{153}$

RUC, in short, pits representatives of "face time" or evaluationand management-intensive providers against procedure-driven providers in the division of the MPFS pie. The very composition of RUC favors providers of invasive, high-technology procedures over primary care and cognitive medicine providers. This outcome was predicted at RUC's founding because of the rise of "lucrative outpatient diagnostic studies" as a growth sector. ${ }^{154}$ This prediction has been particularly prescient. Entire medical specialties - such as family practitioners and geriatricians-do few high-technology procedures, the sine qua non of relative value in the MPFS. Ironically, it is these same evaluation- and management-intensive primary care providers that approve or direct significant amounts in health-care spending per work day. ${ }^{155}$

The current chair of RUC explains the weighting of procedural over cognitive specialties by noting that RUC was never meant to be a representative body. ${ }^{156}$ Although this rationale has been met with considerable scorn by primary care physicians, ${ }^{157}$ it contains more than a kernel of truth. Primary care physicians bemoan their exclusion from RUC and the fact that each seat is filled by a physician who acts as an advocate for a given specialty. ${ }^{158}$ Nevertheless, the lessons that can be extracted from RUC's "failed experiment" 159 are substantial.

Specialty physicians dominate the RUC. This has significance for both Medicare cost inflation and care delivery. American medicine is specialty physician dominated, with primary care physicians ${ }^{160}$ comprising less than half of the total physician group.

15342 U.S.C. $\S 1395 \mathrm{w}-4(\mathrm{p})(4)(\mathrm{C})(2010)$.

154 Shaw, supra note 136, at 21 (quoting Dr. Bruce Sigsbee, first representative of the American Academy of Neurology to the RUC).

155 See Thomas Bodenheimer, Bernard Lo \& Lawrence Casalino, Primary Care Physicians Should Be Coordinators, Not Gatekeepers, 281 JAMA 2045, 2045 (1999).

156 Anna Wilde Mathews, Dividing the Medicare Pie Pits Doctor Against Doctor, WALL ST. J. (Apr. 7, 2011), available at http://online.wsj.com/article/SB10001424052702303341904575576480649488148.ht $\mathrm{ml}$. Nov. 8, 2011)

157 See generally REPLACE THE RUC!, http://replacetheruc.org/ (last visited

${ }_{158}$ Shaw, supra note 136, at 20.

159 Id. at 21.

160 Primary care physicians are defined, for purposes of government funded insurance, as internists, pediatricians, family practitioners, and geriatricians. 42 C.F.R. § 414.66(a). Geriatricians have long sought a geriatrician designated seat on RUC but with no success to date. See Press Release, American Geriatric Society, 
By contrast, virtually all European countries have a broad generalist physician foundation comprising 70-80 percent of all practicing physicians. ${ }^{161}$ The conventional explanation for the primary care and specialty physician distribution in the United States is that primary care is underpaid and undervalued. It is less-often noted that specialty care is concomitantly overvalued, ${ }^{162}$ and the mechanisms by which these perverse outcomes are institutionalized are rarely scrutinized. Without such scrutiny, it is hard to know how a system that rightly values the most efficient Medicare physician services can be implemented.

RUC offers a vivid example of how administered pricing schemes can be captured by those who would benefit from overpayments. ${ }^{163}$ It has also been suggested that RBRVS is destined to produce misvalued codes and that overvalued codes will always lead to spending growth. ${ }^{164}$ If this is true, the problem with health-care overconsumption and overpayment is larger than the problem of Medicare physician payment. If it is also true that an estimated 30 percent of health-care services are unnecessary or duplicative, ${ }^{165}$ it is worth considering how to wring the most obvious inefficiencies out of the system. Reforming RUC would be an excellent place to start.

\section{Reforming RUC}

CMS has been urged to seek independence from RUC when recalibrating RVUs. ${ }^{166}$ MedPAC has recommended that an independent body of experts, composed of a group extending beyond physicians to economists and third-party payers, review RUC recommendations. ${ }^{167}$ It has also been suggested that the IPAB play

Alan Lazaroff, MD, Appointed to RUC Administrative Subcommittee; Update on AGS Response to AAFP's Proposed Changes to the RUC Structure (Aug. 12, 2011), available at $\mathrm{http}: / / \mathrm{www}$.americangeriatrics.org/press/id:2311.

161 J.D. Goodson, Unintended Consequences of Resource-Based Relative Scale Reimbursement, 298 JAMA 2308, 2308 (2007).

162 See Thomas Bodenheimer, Robert A. Berenson \& Paul Rudolf, The Primary Care-Specialty Income Gap: Why It Matters, 146 AnNALs InTERNAL Med. 301, 303 (2007).

163 Frank Pasquale, RUC's Role in Medicare, Balkinization (Oct. 27, 2010, 1:30 PM), http://balkin.blogspot.com/2010/10/rucs-role-in-medicare.html.

164 Reinhardt, supra note 144.

$165 \mathrm{Id}$.

166 Id.

167 MedPaC, Report to the Congress: Medicare Payment Policy 133, 134 (Mar. 2006), available at http://www.medpac.gov/documents/Mar06_EntireReport.pdf. 
this role. ${ }^{168}$ These recommendations, of course, assume that the difficulties of government central planning in health-care markets would be remedied by a differently-composed RUC alone.

Reformulating RUC would also have significant implications for inpatient care. Just as outpatient Medicare physician services have been shaped by RUC's role in recalibrating RVU's, acute care hospitals have oriented much of their service provision toward high value RVUs and high value RVU specialty groups such as cardiology. ${ }^{169}$

RUC operates in substantial obscurity. ${ }^{170}$ Although the identity of RUC appointees is available within the AMA, this information has not been widely circulated. In addition to being disproportionately oriented towards procedural medical specialties, RUC's current appointees are disproportionately male and southern ${ }^{171}$. In addition, almost half of the members of RUC have financial relationships with pharmaceutical companies, biotechnology companies, device companies, health-care providers, and health insurance companies. ${ }^{172}$ Nevertheless, the AMA asserts that RUC members "exercise their independent judgment and are not advocates for their specialty."173 The effect of bias is difficult to measure since RUC's votes are confidential ${ }^{174}$ RUC is reported to have a conflict of interest policy, although it is unknown. The meetings are closed, but CMS is reported to have observers at each meeting. ${ }^{175}$

\footnotetext{
168 Reinhardt, supra note 144.

169 Id.

170 The AMA's website does not list RUC membership by name, for example. The RVS Update Committee, AM. MED. ASS'N, http://www.amaassn.org/ama/pub/physician-resources/solutions-managing-your-practice/codingbilling-insurance/medicare/the-resource-based-relative-value-scale/the-rvs-updatecommittee.page (last visited Jan. 3, 2012).

${ }^{171}$ A current list of current RUC membership and affiliation is most readily accessed through non-AMA sources. See e.g., Roy M. Poses, RUCing AboutConflicts of Interests Affecting the Members of the RBRVS Update Committee, HeAlth CARE Renewal, (Apr. 26, 2011, 5:26 PM), http://hcrenewal.blogspot.com/2011/04/rucing-about-conflicts-of-interest.html.

172 Now a Mainstream Notion: "Profit-Seeking Players in Finance and Health Care Have Captured Congress," Pharmacy Blog: READ Information \& BUY MEDICATION (Aug. 10, 2011), http://pharmacyblogbuy.com/tag/regulatorycapture/.

${ }^{173}$ AMA/Specialty Society RVS Update Committee, AM. MED. ASS'N, http://www.ama-assn.org/resources/doc/rbrvs/toptenthings.pdf (emphasis in original) (last visited Nov. 3, 2011).

${ }^{174} I d$.

175 RUC's proprietary meetings are reported to be closed to members of the public, except by invitation of the chair. Roy M. Poses, "Replace the RUC!'”, HEALTH
} 
The single most important thing to know about RUC is that it has used "flawed and capricious methodologies" that is itself fundamentally flawed. These flaws harm both patients and taxpayers. Not coincidentally, they also harm primary care providers and purchasers. The second most important thing to know about RUC is that it develops new RVUs, and CMS approves them. ${ }^{177}$ Historically, it has taken several years to develop and value new codes. ${ }^{178}$ Needless to say, RUC moves slowly.

RUC serves providers poorly, yet it not been abandoned by providers. This is because RUC serves certain providers very well, and only disserves primary care providers. The largest primary care medical society, the American Academy of Family Physicians (AAFP), is currently studying the implications of abandoning RUC. ${ }^{179}$ The potentially destabilizing effect of such a decision by an entity representing roughly 10 percent of the country's primary care providers cannot be ignored. AAFP's New Jersey and Florida chapters have already called for the AAFP to quit RUC. ${ }^{180}$

Most recently, a Maryland-based group of primary care physicians has brought suit against CMS for ceding control of the Secretary's rulemaking process to RUC and for failing to properly constitute the RUC as a Federal Advisory Committee. ${ }^{181}$ Although the case has only recently been filed, review of CMS's memorandum in support of its 12(b)(6) motion indicates that CMS takes the position that RUC is a creature of the AMA and not a federal advisory committee. ${ }^{182}$ It remains to be seen whether the most significant

\footnotetext{
$\begin{array}{llllll}\text { CARE RENEWAL } & \text { (Feb. } & 25, & 2011, & 4: 46 & \text { PM), }\end{array}$ http://hcrenewal.blogspot.com/2011/02/replace-ruc.html.

176 Brian Klepper et al., Stifling Primary Care: Why Does CMS Continue to Support the RUC?, HeAlth CARE Blog (May 25, 2011), http://thehealthcareblog.com/blog/2011/05/25/stifling-primary-care/.

177 Ariel Winter, Improving Payment Accuracy and Appropriate Use of Ancillary Services, MEDPAC 1, 5 (Apr. 7, 2011), available at, http://www.medpac.gov/transcripts/ancillary\%20services_April\%202011_public.pdf. 178 Id. at 6.

179 Sheri Porter, AAFP Addresses RUC Subcommittee Regarding Changes the Academy Seeks, AM. ACAD. OF FAMily Physicians (Sept. 26, 2011, 4:15 PM), http://www.aafp.org/online/en/home/publications/news/news-now/practiceprofessional-issues/20110926goertztoruc.html.

180 Brian Klepper, Facing Uncertainty: Why Primary Care Doctors Must Act Now, REPLACE THE RUC! (Apr. 23, 2011), http://replacetheruc.org/2011/04/23/facinguncertainty-why-primary-care-docs-must-act-now/.

181 Complaint at 1-2, Fischer v. Berwick, No. 1:11cv02191-WMN (D. Md. Aug. 8, 2011), 2011 WL 3665650.

${ }_{182}$ Memorandum of Points and Authorities in Support of Defendants' Motion to Dismiss at 1-3, Fischer v. Berwick, No. 1:11 cv02191-WMN (D. Md. Nov. 10, 2011).
} 
byproduct of this litigation will be an airing of RUC's operation. What is clear is that CMS appears unwilling to cede ground on their position that the Medicare statute does not permit either administrative or judicial review of the determination of relative values. $^{183}$

Although primary care physician distaste for RUC is apparent, it is rarely noted that RUC also serves patients poorly, though it has not been attacked by patients. This is because few patients understand RUC and the implications of its valuation of physician services for the quality, quantity, and cost of care that they receive. Also, patients are the ultimate end-users of health care in our hybrid system. As such, they are also often insulated from cost and a comprehensive understanding of health-care cost drivers.

If RUC serves payors so poorly, why has it not been abandoned? Payors, including the biggest payor of them all, the United States government, have been reluctant to abandon RUC in light of the failure to identify a clearly superior alternative. RUC embodies many of the flaws of self-regulated fee-for-service medicine while also embodying the political stalemate over funding physician services through government-funded health insurance, leaving many persuaded that progress is impossible. In addition, primary care providers have not leveraged their role as the specialty care referral base into financial concessions from other physicians. ${ }^{184}$

Even the modest proposal that any medical services valuation panel include a broader array of health-care experts (including nonprovider experts $)^{185}$ has met with ferocious criticism from providers. ${ }^{186}$ More ambitious proposals (e.g., requiring CMS to fund direct surveys of medical practice and resources) ${ }^{187}$ scarcely see the light of day.

It has become an anathema to mention financial incentives for physicians when discussing reform of payment for physician services under government-funded health insurance. Yet, since physician decisions drive most health-care costs, it is impossible to address physician payment without addressing physician motivation. As a

183 Id. at 14.

184 Klepper, supra note 180.

185 Reinhardt, supra note 144.

186 See, e.g., Klepper, supra note 180.

187 Robert Berenson proposed something very similar to this. Joe Eaton, Powerful Medical Insiders Make Determinations on Medicare, The CutTING EdGE (Nov. 8 , 2010)

http://www.thecuttingedgenews.com/index.php?article=21768\&pageid=89\&pagenam $\mathrm{e}=$ Features (quoting Robert Berenson on his efforts to promote better valuation by CMS). 
result, in our public discourse we simply talk around the issue.

Unfortunately, continued specialty physician dominance of the physician services valuation system stifles the discourse about whether physician services are appropriately valued and the larger discourse about self-regulation in government-funded health insurance. Given the current stalemate over how to proceed, we might learn from the stalemate that plagues the debate regarding acceptable growth rates for physician services payments.

\section{E. The Physician Payment Sustainable Growth Rate Formula}

Controls on aggregate Medicare physician spending have helped suppress the growth of Medicare costs ${ }^{188}$ over the last three decades. ${ }^{189}$ The staged introduction of Medicare's prospective payment systems have demonstrated that spending growth is responsive to policy interventions, ${ }^{190}$ but not all reforms have worked equally well in all settings. Excess spending growth in physician and clinical services has proven particularly intransigent. ${ }^{191}$ The story of why this is sowhy excess Medicare spending growth in hospital care expenses has been tamed by changes in Medicare's payment policies, and why excess Medicare spending growth in physician services has nothelps to explain the IPAB's design and function. It is the story of the failure of Congress to implement Medicare's SGR formula for Medicare physician services that helps to explain the IPAB's impetus.

Congress has affirmatively refused to change the payment incentives for doctors, while acknowledging physician decisions drive most health-care costs, because physicians have not embraced Medicare physician payment reform. ${ }^{192}$ Congress has now decided to take matters out of its own hands: "All Congress can do is fully replace an IPAB recommendation with a reform that saves the same amount of money or muster both a supermajority and a presidential

188 Medicare's excess growth or spending growth beyond what may be attributed to general economic growth is often referred to as Medicare inflation or Medicare's growth rate. Bending the cost curve refers to the capacity to limit Medicare's spending growth to what may be attributed to general economic growth. The LongTerm Outlook for Health Care Spending, supra note 8.

189 White, supra note 91, at 796-97.

190 Id. at $795-98$.

191 Id. at 796-97.

192 Ian Morrison, Chasing Unicorns: The Future of ACOs, HosP. \& HEALTH NETWORKS WKLY. (Jan. 3, 2011), http://www.hhnmag.com/hhnmag_app/jsp/articledisplay.jsp?dcrpath=HHNMAG/Arti cle/data/01JAN2011/010411HHN_Weekly_Morrison\&domain=HHNMAG. 
signature to stop IPAB from acting. Either path requires a lot more effort than undermining cost control does right now." 193

Ambivalent about physician reimbursement's role in Medicare excess spending, Congress has intermittently frozen fee levels, ${ }^{194}$ reduced fees for certain procedures, ${ }^{195}$ and introduced a fee schedule with spending targets. ${ }^{196}$ Even more ambivalent about its role in keeping excess Medicare physician growth in check, Congress has overridden the fee schedule consistently and regularly since its introduction in $1992 .{ }^{197}$

The SGR formula requires that if the growth of Medicare's total payments to physicians exceeds GDP growth by a certain amount in a given year, reimbursements will decrease. Medicare adopted the SGR formula in the 1990's as part of the Gingrich-Clinton balanced budget negotiations. However, the SGR did not begin to bind until 2003, when the growth of Medicare's total benefits per beneficiary exceeded the growth rate of GDP per capita. Then the across-the-board cuts to physicians accepting Medicare assignments mandated by the SGR formula began to accumulate. Congress promptly postponed implementation of the SGR. Congress has yet to allow the SGR formula to kick in. Because the SGR formula cuts Medicare payments to all physicians - well-compensated or otherwise - it has raised concerns of reduced access to care for Medicare beneficiaries. And, because the SGR formula is a rallying cry for organized medicine's fear of falling income and status, it has a perverse usefulness to its proponents and opponents alike. Unfortunately, "virtually everyone in Washington understands that the SGR formula will never be implemented." 198

The cumulative unimplemented cuts are now projected to equal a 29.4 percent SGR cut in the Medicare physician growth rate. ${ }^{199}$

193 Ezra Klein, Of Course Many in Congress Don't Want to Control Medicare Costs, WAsh. Post WonkBlog (Apr. 20, 2011, 10:54 AM), http://www.washingtonpost.com/blogs/ezra-klein/post/of-course-many-in-congressdont-want-to-control-medicare-costs/2011/04/13/AFDXcwBE_blog.html.

194 White, supra note 91 , at 797.

195 Id.

196 Id. at 796-97.

197 Peter Suderman, The Doc Fix: A Lesson in How Government Doesn't Work, REASON: Hit AND Run, (Dec. 16, 2011) http://reason.com/blog/2011/12/16/thedoc-fix-an-object-lesson-in-how-gove.

198 Mahar, supra note 105. See also A Plan to Fix the Dreaded SGR Formula?, AM. J. MANAGED CARE (Oct. 17, 2011), http://www.ajmc.com/focus-of-theweek/1011/sgr-focus-101711.

199 Andis Robeznieks, CBO Sees 29.4\% Medicare Rate Cut for Docs in January, ModernPhysician.com (June 15, 2011, 2:45 PM), 
Acknowledging that a January 1, 201229.5 percent cut to Medicare physician payments would be detrimental to beneficiary access to care, ${ }^{200}$ MedPAC urged Congress to resolve the SGR formula conundrum. By October of 2011, MedPAC's dissatisfaction with the SGR formula had escalated to the point of urging its repeal and replacement by a yearly schedule of specified updates for the physician fee schedule as well as a 17 percent across-the-board cut in Medicare specialty fees. ${ }^{201}$ But specialty physician pushback has been substantial. ${ }^{202}$

In light of this, several options are now on the table. One option would be to embrace the 29.4 percent SGR-related cut to the Medicare physician growth rate. This would almost certainly cause some contraction in those physicians accepting Medicare assignment, but would likely not lead to the alarmist prediction of the wholesale collapse of Medicare assignment. ${ }^{203}$ Among private physicians, Medicare is the preferred payer, with about 93 percent of American physicians willing to accept Medicare beneficiaries as patients. ${ }^{204}$ Embracing the 29.4 percent SGR-related cut to the Medicare physician growth rate would mean Medicare might deepen its reputation as a less than optimal payor without harming its reputation as a reliable and, consequently, favored payor. ${ }^{205}$ If past is prologue, however, we are unlikely to have the chance to find out what such a significant cut to Medicare physician growth rate would mean for Medicare beneficiaries. This option is unpalatable to Congress. ${ }^{206}$

\footnotetext{
http://www.modernphysician.com/article/20110615/MODERNPHYSICIAN/3061599 81.

200 See MedPaC, Report to Congress: Medicare Payment Policy xiv (Mar. 2011) available
http://www.medpac.gov/documents/Mar11_EntireReport.pdf.

http://www.medpac.gov/documents/Mar11_EntireReport.pdf.
201 Letter from Glenn M. Hackbarth, Chairman of MedPac to Senator Max Baucus et. al, 8 (Oct. 14, 2011), available at www.medpac.gov/documents/10142011_medpac_sgr_letter.pdf.

202 Letter from the Alliance of Specialty Medicine to MedPac Chairman Glenn M. Hackbarth (Sept. 26, 2011), available at http://www.specialtydocs.org/weblev/user_upload/Alliance_Letter_MedPAC_SGR.p df.

203 Although Medicare assignment rates have long been shown to be sensitive to reimbursement and administrative practices, the most recent data shows only a very modest decline in physician acceptance of new Medicare patients. Compare Janet B. Mitchell \& Jerry Cromwell, Physician Behavior under the Medicare Assignment Option, 1 J. Health Econ. 245, 262-63 (1982), with Tara F. Bishop et al., Declines in Physician Acceptance of Medicare and Private Coverage, 171 ARCHIVES INTERNAL MED. 1117, 1118 (2011).

${ }^{204}$ Bishop et. al., supra note 203, at 1118.

205 Id.

206 Suderman, supra note 197.
} 
A second option would, much as MedPac has only recently done, be to abandon the SGR formulation entirely and urge Congress to develop a revised physician payment system. ${ }^{207}$ Abandoning the SGR formulation would reduce provider interest in Medicare physician payment reform, however.

A third option would be to use the looming SGR-related cut to generate pressure to establish a new Medicare physician services payment system, an approach advanced by the National Commission on Fiscal Responsibility and Reform. ${ }^{208}$

Instead, Congress has routinely overridden the SGR and MedPAC continues to spin out proposals to resolve the SGR formula dilemma, most recently no fewer than four potential fixes centered around simply repealing the SGR.

In the meantime, the ACA's launch of the IPAB draws closer, in the face of a constitutional challenge to its validity. This challenge, often hidden in the shadow of other constitutional attacks on the ACA, merits some thought.

\section{Constitutional Challenges to IPAB}

\section{A. Separation of Powers}

The IPAB's lynchpin is the limitation of specialty physician control over discussions about Medicare physician reimbursement. This process is described disparagingly as "government of, by, and for supposedly disinterested experts," 209 and the IPAB's mission is to insulate the conversation about cost effective Medicare reimbursement rates from specialty provider dominance. The IPAB's operational model does, in fact, substitute one group of congressionally-authorized and executive branch-selected health-care

207 See The Need to Move Beyond the Sustainable Growth Rate in Medicare: Hearing Before the House Energy \& Commerce Committee, Subcommittee on Health, 112th Cong. 2 (2011) (statement of Mark B. McClellan, Director, Engelberg Center for Health Care Reform), available at http://republicans.energycommerce.house.gov/Media/file/Hearings/Health/050511/M cClellan.pdf (urging the Subcommittee to look beyond approaches that remain tied to the existing formula simply by delaying it again, or by resetting baselines to higher spending levels). See also, Abby Goodnough \& Kevin Sack, Massachusetts Tries to Rein in Its Health Cost, N.Y. TIMES, October 18, 2011, at A1 ("Those who led the 2006 effort to expand coverage readily acknowledged that they deferred the more daunting taks of cost control for another day.")

208 NAT'L COMM'N ON FiSCAL RESP. \& REFORM, supra note 71, at 31-35.

209 George F. Will, Government by the 'Experts,' WASH. PosT. (June 10, 2011), available at http://www.washingtonpost.com/opinions/government-by-theexperts/2011/06/09/AGpU1KPH_story.html. 
experts for the specialty physician experts who dominate RUC. Ultimately, both the status quo and the IPAB's model involve extensive use of experts. The status quo unofficially delegates authority to specialty physicians through the RUC process and the ACA explicitly delegates authority to the IPAB.

Among the twenty-eight federal cases challenging the ACA, the Goldwater Institute's Coons v. Geithner ${ }^{210}$ frames the separation of powers challenge to the IPAB's organization around the broad authority delegated to the IPAB by Congress. Asserting that the ACA "provides almost no limit on and no intelligible standard constraining the exercise of legislative power by IPAB," the complaint seeks to test the modern parameters of Supreme Court deference to Congressional delegation of authority. ${ }^{211}$

Congressional authority to delegate power under broad general directives is recognized as necessary for Congress to resolve especially technical problems. ${ }^{212}$ The limit on congressional authority to delegate lies in the requirement that Congress include an "intelligible principle" to guide the conduct of agent. ${ }^{213}$

The IPAB's statutory mandate is to find ways to "reduce the per capita rate of growth in Medicare spending." 214 This mandate is constrained by the requirements that the proposals be specific, focus on extending Medicare solvency, and protect and improve Medicare beneficiaries' access to necessary and evidence-based items and services. $^{215}$ The ACA's guidance for the exercise of the IPAB's discretion is substantial, substantially broader than the intelligible principle identified in the Emergency Price Control Act litigated in Yakus v. United States. There, the congressional mandate was to set prices at levels "generally fair and equitable," ${ }^{216}$ with the specific parameters of discretion read into the statute from the legislative history. ${ }^{217}$ The substantial discretion granted to the Secretary of Health and Human Services in transforming the IPAB's

210 Coons v. Geithner (Federal Health Care Lawsuit), Goldwater InSTITUTE (Aug. 12, 2010), http://www.goldwaterinstitute.org/article/coons-v-geithner-federalhealth-care-lawsuit.

211 Second Amended Civil Rights Complaint for Declaratory and Injunctive Relief at 31, Coons v. Geithner, No.2:10cv1714 (D. Ariz., May 10, 2011).

212 Mistretta v. United States, 488 U.S. 361, 372 (1989).

213 Id. (quoting J.W. Hampton, Jr., \& Co. v. United States, 276 U.S. 394, 409 (1928)).

21442 U.S.C. $\S 1395 \mathrm{kkk}(\mathrm{b})(2011)$.

215 Id. $\S 1395 \mathrm{kkk}(\mathrm{c})(1)(\mathrm{A}), 1395 \mathrm{kkk}(\mathrm{c})(2)(\mathrm{B})(\mathrm{i})(\mathrm{I})-(\mathrm{II})(2010)$.

216 Yakus v. United States, 321 U.S. 414, 419-20 (1944) (delegating to an executive branch official the ability to set maximum wartime prices for commodities).

217 Id. at 420 . 
recommendations as they are forwarded to Congress raises questions about the permissible scope of the intelligible principle created to guide the conduct of the agent. ${ }^{218}$

The IPAB's authorizing legislation is remarkably detailed as to the limitations on its authority. It is these very detailed limitations that make IPAB's task so daunting. ${ }^{219}$ In addition, the Supreme Court has shown remarkable deference to congressional delegation of authority. The only two Supreme Court cases indicating federal statutes lacked the necessary intelligible principle to constrain board or agency action concerned delegations of authority lacking the ACA's substantial limitations on IPAB authority. ${ }^{220}$ In addition, no law has been struck down under a delegation challenge since the 1930 s. $^{221}$ IPAB's framers were careful to constrain its authority over matters beyond Medicare payment reform.

\section{CONCLUSION}

In order to blunt resistance to Medicare by physician interest groups, President Lyndon Johnson proposed a payments system for Medicare with minimal oversight: doctors would charge Medicare what they charged their other patients for the services that they, the doctors, deemed to be medically appropriate. But while private insurers and individuals paying out-of-pocket could, and did, inquire as to how appropriate and necessary the various procedures were, Medicare, as originally established, did not.

By the 1980s it was clear that if Medicare was to be sustained over the long run it needed more oversight of the payments system. The option chosen was Dr. William Hsiao's "medical Taylorism": 222 determine how much it ought to cost to treat this condition and perform this service - based on the locality and the time, effort, skill, and stress involved - and then base Medicare reimbursement rates on

218 See Bowsher v. Synar, 478 U.S. 714, 720-21 (1986) (striking down the Gramm-Rudman-Hollings Act as an unconstitutional exercise of executive power by the Congress under a scheme commanding the executive as to specific spending decisions).

219 See 42 U.S.C. $\S 1395 k k k$ (2010).

220 See A. L. A. Schechter Poultry Corp. v. United States, 295 U.S. 495, 54142 (1935); Panama Ref. Co. v. Ryan, 293 U.S. 388, 430 (1935).

221 Peter Suderman, Scalia vs IPAB?, Goldwater Institute (July 15, 2011),http://www.goldwaterinstitute.org/article/scalia-vs-ipab.

${ }^{222}$ The term we coin is an analogy to the Taylorist movement of the early twentieth century for the rationalization of industrial processes. See Frederick W. TAYlor, The Principles of SCIENTIFIC MANAgEMENT 15 (1913) ("the self-evident fact that maximum prosperity can exist only as the result of the determined effort of each workman to turn out each day his largest possible day's output"). 
that determination. Once again, however, the system is out of balance. Just as insurance company regard for bottom lines and household regard for individual spending were missing from the original system, so too the current system overvalues specialty medical procedures, because specialists have the expertise, free time, and incentive to shape the process in their own interest.

The IPAB is designed to redress this imbalance. With publiclyannounced membership and open procedures, the IPAB is designed to bring conversations over Medicare physician compensation into the public forum. The Obama administration is placing many of its longrun hopes for sustaining the social insurance system on the IPAB. Even though the IPAB will not to spring into existence until 2012, throughout 2011 the same principles governed President Obama's federal health-care spending control strategy: "by strengthening an independent commission of doctors, nurses, medical experts, and consumers who will look at all the evidence and recommend the best ways to reduce unnecessary spending while protecting access to the services that seniors need." 223

Expert boards have always run the risk of being captured by the industry that they are supposed to regulate. Indeed, the Medicare reimbursement process has already been captured, and the need to substitute an open and informed process for the RUC's rubberstamping of specialist-driven outpatient physician service valuation is great. The Medicare payment systems bellwether status means that commercial insurance consumers and payers would also benefit from bringing the discussion of the systematic overvaluation of specialty care and devaluation of primary care out into the open.

The ACA is peppered with programs designed to raise the status and value of primary care providers. But all of this will be for naught if primary care services are not properly validated and valued in Medicare.

223 President Barack Obama, Speech on Reducing the Budget (Apr. 13, 2011), available at http://www.nytimes.com/2011/04/14/us/politics/14obama-text.html. 